\title{
Alternative liquid fuels in the UK in the inter-war period (1918-1938): Insights from a failed energy transition
}

\author{
Document Version \\ Other version
}

Link to publication record in Manchester Research Explorer

\section{Citation for published version (APA):}

Johnson, V., Sherry-Brennan, F., \& Pearson, P. (2016). Alternative liquid fuels in the UK in the inter-war period (1918-1938): Insights from a failed energy transition. Environmental Innovation and Societal Transitions.

\section{Published in:}

Environmental Innovation and Societal Transitions

\section{Citing this paper}

Please note that where the full-text provided on Manchester Research Explorer is the Author Accepted Manuscript or Proof version this may differ from the final Published version. If citing, it is advised that you check and use the publisher's definitive version.

\section{General rights}

Copyright and moral rights for the publications made accessible in the Research Explorer are retained by the authors and/or other copyright owners and it is a condition of accessing publications that users recognise and abide by the legal requirements associated with these rights.

\section{Takedown policy}

If you believe that this document breaches copyright please refer to the University of Manchester's Takedown Procedures [http://man.ac.uk/04Y6Bo] or contact uml.scholarlycommunications@manchester.ac.uk providing relevant details, so we can investigate your claim.

\section{OPEN ACCESS}



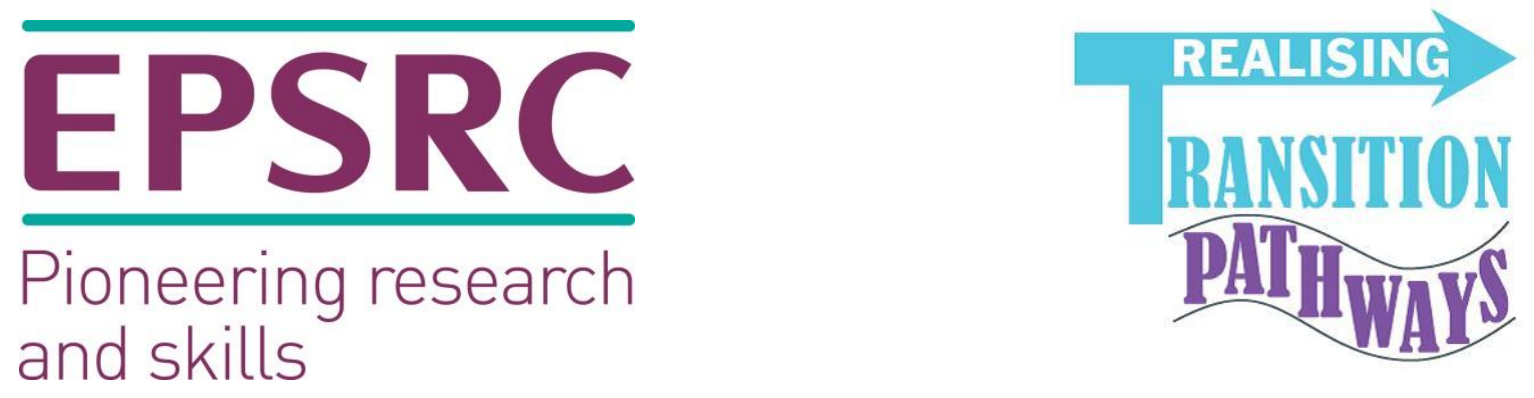

\section{Alternative liquid fuels in Britain in the inter-war period (1918- 1938): Insights for future energy transitions}

Victoria C A Johnson ${ }^{1}$, Fionnguala Sherry-Brennan², Peter J G Pearson

Low Carbon Research Institute, Cardiff University

WP 2014/1

4 March 2014

Realising Transition Pathways

Whole systems analysis for a UK more electric low carbon energy future

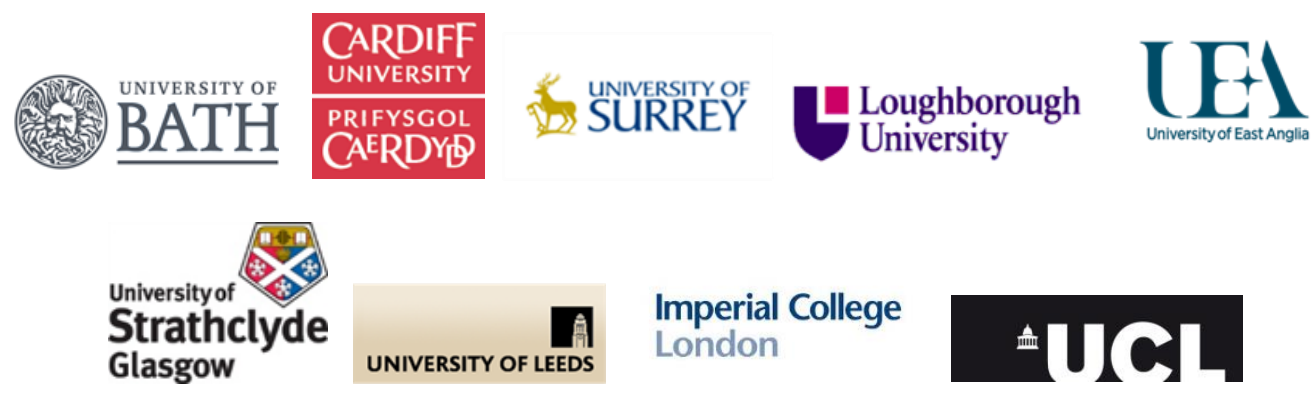

\footnotetext{
${ }^{1}$ Research and analysis of $\mathrm{ICl}$ case study

${ }^{2}$ Research and analysis of DCL case study
} 


\section{Realising Transition Pathways}

'Realising Transition Pathways' (RTP) is a UK Consortium of engineers, social scientists and policy analysts. The consortium is managed by Professor Geoffrey Hammond of the University of Bath and Professor Peter Pearson of Cardiff University (Co-Leaders). It includes research teams from nine British university institutions: the Universities of Bath, Cardiff, East Anglia, Leeds, Loughborough, Strathclyde, and Surrey, as well as Imperial College London and University College London. The RTP Project [www.realisingtransitionpathways.org.uk] commenced in May 2012 and is sponsored by the 'Engineering and Physical Sciences Research Council' (EPSRC: Grant EP/K005316/1). It is a renewal and development of the earlier 'Transition Pathways' (TP) project, which was initially established in 2008 with the joint sponsorship of E.ON UK (the electricity generator) and the EPSRC. This project addressed the challenge of the so-called energy 'trilemma': the simultaneous delivery of low carbon, secure, and affordable energy services for the electricity sector. It developed and applied a variety of tools and approaches to analyse the technical feasibility, environmental impacts, economic consequences, and social acceptability of three 'transition pathways' towards a UK low carbon electricity system. These pathways explore the roles of market, government and civil society actors in the governance of a low carbon energy transition.

The research within the RTP Project seeks to explore further the constraints and opportunities in realising a low carbon UK energy sector, including those stemming from European developments. This project includes studies on the horizon scanning of innovative energy technologies over the period to 2050, the feasibility of demand responses, uncertainties in economic analysis, the estimation of investment costs of the different pathways, and the implications of markets for investment decisions about energy technologies. Further work is being undertaken on conceptualising, mapping and analysing 'actor dynamics' in the contemporary UK electricity sector, historical transitions and case studies, integrated energy networks modelling and evaluation, and 'whole systems' energy and environmental appraisal of low carbon technologies and pathways. The consortium is also developing their initial work on branching points on pathways, in order to identify and explore other potential branching points on the core transition pathways.

Follow us on Twitter @RealisingTP

This document has been prepared to enable results of on-going RTP work to be made rapidly available. It has not necessarily been subject to review and approval, and may not have the authority of a full Research Report or published paper 


\section{CONTENTS}

Section

Abstract $\quad 4$

1. Introduction 5

$\begin{array}{lll}1.1 & \text { Analytical approach } & 6\end{array}$

1.2 Coal to oil transition in the transport sector 8

1.3 Energy security during the inter-war period 9

1.4 Macroeconomic context 13

$\begin{array}{lll}1.5 & \text { The amalgamation movement } & 15\end{array}$

2. Power alcohol (DCL) 16

3. Petrol-from-coal (ICI) 19

$3.1 \mathrm{ICl}$ and coal-hydrogenation $\quad 19$

3.2 The emergence of coal-hydrogenation in Britain $\quad 20$

$\begin{array}{ll}3.3 \text { State support for coal hydrogenation } & 22\end{array}$

3.4 State-industry relations 24

3.5 The economic case for petrol-from-coal $\quad 25$

4. Key features of the case studies and the analytical themes 26

5. Discussion: Insights from ICl and DCL's common experiences 29

5.1 Energy security 29

$\begin{array}{lll}5.2 & \text { State support } & 29\end{array}$

$\begin{array}{lll}\text { 5.2.1 Strategic industries and organised research } & 30\end{array}$

$\begin{array}{lll}\text { 5.2.2 Government and industry relationships } & 30\end{array}$

5.3 Oil major hegemony: fuel distribution and patent pool agreements 31

5.4 Differences between ICl and DCL case-studies 32

6. Conclusions and policy implications 33

References $\quad 36$ 


\title{
Alternative liquid fuels in Britain in the inter-war period (1918-1938): Insights for future energy transitions
}

\begin{abstract}
Against a backdrop of growing interest in the development of low carbon alternatives to petroleum derived liquid fuels, this paper provides an analysis of earlier experiences of the emergence and evolution of alternative liquid fuels. We argue such analyses can provide useful insights for future energy transitions and in particular the governance of such transitions. This paper focusses on two alternatives to petrol manufactured in the UK during the inter-war period (1918-1938). The two fuels were power alcohol, made by the Distillers Company Ltd. (DCL) and sold as Discol between 1921 and 1973, and a petrol-from-coal made by Imperial Chemical Industries Ltd. (ICI), which was blended with petroleum derived petrol and sold between 1935 and 1958. Here we examine the background to the emergence of these fuels, the actors involved and their combined roles. We find both fuels received government support during a time of rapid growth in the motor industry, fluctuating economic conditions, fears of absolute oil shortages, and the desire to develop the UK's chemical industry. Both fuels were considerably affected by changing political thinking around energy security and oil major hegemony; governance of fuel distribution in particular had significant effects on both fuels. We discuss how changing modes of governance, between market and state logics, created hybrid governance conditions. These conditions reflected state intervention to support new fuels and a failure to regulate the market for fuel distribution. Therefore, whilst hybrid governance provided government with the flexibility to respond quickly to changing circumstances, unresolved tensions between policies made it more difficult for alternative fuels to thrive.
\end{abstract}

\section{Highlights}

- The changing shape of energy security affected government support for alternative fuels in the interwar period.

- During periods of heightened energy security concerns, liquid fuels were considered as a 'special article' rather than a 'market commodity', and subject to a greater degree of state intervention.

- Incumbent oil company cartelisation and control of fuel distribution impeded emergence of new fuels.

- Multiple drivers for alternative fuels included concerns about the volatility of crude oil markets, support for a crumbling coal industry, and meeting militaristic needs.

- Policy inconsistency led to the creation of difficult conditions for the development of alternatives to petrol.

- The state- market-led hybrid governance mode of energy policy contributes to conflicting policy measures, thereby making long-term visions and strategies for future energy transitions problematic.

\section{Keywords}

Alternative fuels, chemical industry, coal hydrogenation, DCL, energy security, energy transition, fuel distribution, governance, subsidies, $\mathrm{ICl}$, oil companies, power alcohol, recession 


\section{Introduction}

This paper explores the evolution and eventual demise of two liquid fuels developed in Britain during the inter-war period (1918-1938) with government support. Pressures to develop alternatives to crude oil derivatives grew after World War One (WWI) with the rapid expansion of national and international (motorised marine, land and air) transport. Building on Bennett (2009) and Bennett and Pearson (2009), this paper focusses on power alcohol produced by the Distillers Company Ltd (DCL) and petrol derived from coal by Imperial Chemical Industries Ltd (ICI). While extensive business histories of $D C L$ and ICI have been written elsewhere (e.g. Weir, 1995 for DCL; Reader, 1975; 1977 for ICI), this paper differs from these analyses by specifically concentrating on the fuels they produced, their interactions with other actors, the changing macroeconomic context, and the implication of these for policy. We illustrate how historical experiences of alternative fuel development in Britain were influenced by the changing shape of energy security and changing forms of governance, and reflect on the insights that these experiences offer into low carbon energy transitions.

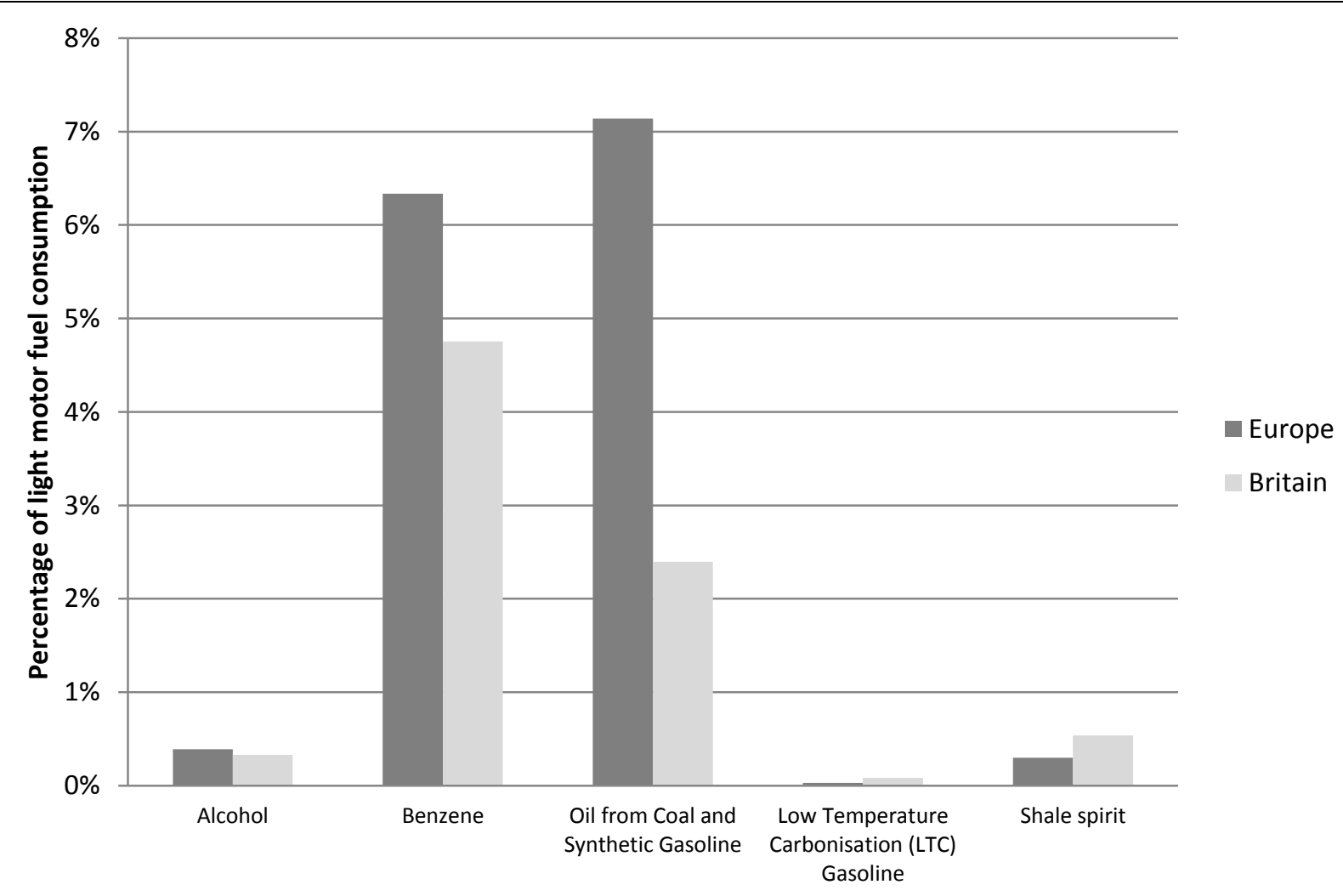

Figure 1: European ${ }^{3}$ and British synthetic fuel consumption as a percentage of total light motor fuel consumption, 1937 (Egloff, 1938).

Experimentation with alternatives to liquid fuels derived from petroleum was commonplace during the first decades of the 20th century. It reached a climax in the inter-war period, particularly among countries that

${ }^{3}$ Countries included: Germany, Estonia, Czechoslovakia, Lithuania, Hungary, Poland, Latvia, Yugoslavia, Belgium, France, United Kingdom, Austria, Sweden, Holland, Finland and Switzerland. 
had no petroleum resources of their own, including Great Britain (See Figure 1: Egloff, 19384). These alternatives were rarely economically competitive, however, and required various forms of state support (Committee on Industrial Alcohol, 1905; Falmouth Committee, 1938; San Román and Sudriá, 2003).

Both power alcohol and petrol-from-coal received direct and indirect state support in Britain during the inter-war period. Here, direct support refers to state subsidies, whilst indirect support relates to support for research, development, and demonstration (RD\&D) through a state run research institution, the Fuel Research Board, the provision of research grants, and the testing of $\mathrm{ICI}$ and DCL's fuels carried out by the Admiralty and Air Ministry.

The remainder of Section one outlines the broader context of the inter-war period, including a brief history of the coal to oil transition, perspectives on energy security, oil company development, macroeconomics and the amalgamation movement in the UK. First, however, we begin with an outline of the analytical approach adopted in this paper. Sections two and three present brief histories of power alcohol produced by $\mathrm{DCL}$ and petrol-from-coal developments made by ICI. These histories detail raw material use and technological development, responses to competition from overseas, relations with the state, fuel blending, and interactions with oil companies. Section four draws together key features of the case studies and the analytical themes. The Discussion in Section five reflects on insights from ICl and DCL's common experiences and on differences between the two cases. Section six concludes by considering insights for future energy transitions arising from the history of these alternative fuel developments.

\subsection{Analytical approach}

The research presented in this paper forms part of the Realising Transitions Pathways project and builds on earlier historical studies (Arapostathis et al., 2013; Carlsson-Hyslop and Pearson, 2013; Pearson and Foxon, 2012). Basing our analysis on earlier experiences of the emergence and evolution of alternative liquid fuels, this paper aims to provide a useful historical analogue for understanding the development, support and acceptance of technological substitutes within socio-technical transitions.

Taking into consideration recent criticisms that socio-technical transitions research often underplays or neglects issues of governance, agency and power (Hughes and Strachan, 2010; Smith et al., 2005) we play particular attention to the role of actors and governance to better understand the drivers for state support for alternative liquid fuels. We do this by exploring the dynamics of the search for, and provision of, state support of DCL and ICl's liquid fuels during the inter-war years. This is achieved by looking at various factors, including the role of macroeconomic conditions, economic aspects of the two liquid fuels (viz. economic appraisal and its significance in decision making), the impact and drivers of shifts in governance logics or 'framings' on state support and the role of different actors.

In order to examine shifts in governance, and the influence of this on prioritisation and framing of energy security and policy responses, we draw on the 'action space' approach developed by the Realising Transition Pathways project team (Foxon, 2013). The action space approach envisions that the pathway of transitions in socio-technological systems arise through the dynamic interaction of technological and social factors, mediated by the actions and actors within an action space. According to the model, three broad types of actor influence change: government actors; market actors, such as large energy firms; and civil

\footnotetext{
4 (Figure 1) Benzene is a refined version of Benzole, a liquid fuel derived from coal-gas or coal-tar. Benzene, benzole, and benzol, were used interchangeably in the historical literature. For the rest of the paper we use the term benzole.
} 
society actors, such as community and environmental groups and households. Foxon (2013) explains how these different actors have fundamentally different 'logics' or framings of the key energy challenges. The logic that dominates a pathway will have a crucial influence on policy choices made and the shape of any future energy system. Different logics can lead to different approaches to policy challenges, including energy security.

In particular, we consider how threats to energy security in the context of liquid fuels drove shifts in state support for alternative liquid fuels during the inter-war period. In post-WWII energy policy, several authors have identified that during periods of price instability of energy (liquid fuels or electricity) or other concerns regarding energy insecurity, a state logic tends to prevail. This is in contrast to times of price stability or robust energy security when a market logic prevails (Helm, 2005; Grimston, 2010; Goldthau, 2012).

Although referring specifically to electricity, Grimston (2010) describes a useful way of examining the dynamic between state and market logics and the impact this has on energy policy. He argues that energy is either framed as a 'social service' or a market commodity. When energy is perceived as a social service, governments tend to intervene in, or even control, delivery systems in a more fundamental way. In contrast, when energy is perceived to be a market commodity there is minimal government intervention in the marketplace beyond the measures required to prevent unfair competition and the internalisation of economic externalities such as environmental effects. Others have also described this dynamic (Helm, 2005; Fudge, 2011; Goldthau, 2012; Rydin et al. 2013; Bolton and Foxon, 2013). However, as Grimston (2010) and Bolton and Foxon (2013) argue, this is often a false dichotomy. Instead, hybrid governance logics often persist which comprise both market-mechanisms and state interventions.

In the context of our case studies and the period under analysis, we consider the dynamics of when liquid fuels were considered as a 'special article[s] of warlike material' or an 'article of general consumption' (Jones, 1981: 18). We argue that these two framings map in a similar way to Grimston's 'social service' or 'commodity' on to state or market logics. This model is illustrated in Figure 2 below.

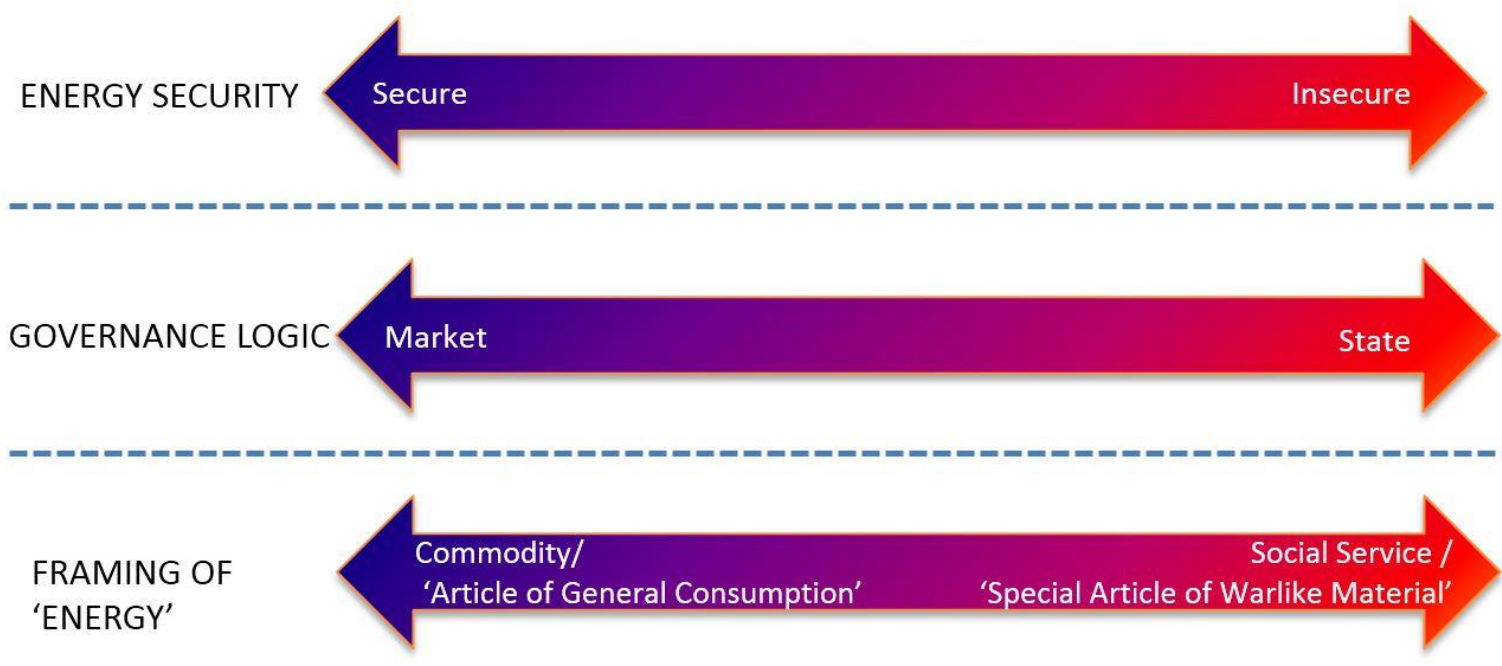

Figure 2: the relationship between governance logic, energy security and the framing of energy within policy. 
Within the wider socio-technical transitions literature our approach in this paper adopts a 'flat ontological' approach (Chilvers and Longhurst, 2013) in contrast to the more commonly used multi-level perspective (Geels, 2002). This approach enables us to consider the co-production of technologies and infrastructures within changing macroeconomic, political, and social conditions, contributing to the field by combining technological development with governance perspectives. Using original documentary material and secondary literatures, we examine how technological developments, prevailing macroeconomic conditions and changing ideologies, relationships between industry and government and within the fuel industry itself contribute to the governance and ultimate demise of power alcohol and petrol-from-coal.

\subsection{Coal to oil transition in the transport sector}

While the economic and defence benefits of liquid fuels were increasingly recognised before WWI (e.g. Royal Commission on Fuels and Engines, 1913), it was only after WWI that imports of crude oil and other derivatives grew rapidly (Figure 3). This was in response to increasing demand from the naval and marine mercantile sectors, and rapid growth in motorcar ownership, road freight, and aviation. Additionally, the infrastructure for liquid fuel distribution had developed considerably during WWI, reducing fuel cost. Coupled to the growing societal acceptance of liquid fuels (Podobnik, 2006), by the 1920s a cultural narrative developed that the 'oil age' represented significant technological progress and was unstoppable (e.g. Lawton, 1925; Brownlie, 1926; Brunner, 1931; Cadman, 1931; The Institute of Fuel, 1936). For example in his extended essay 'The Problem of Oil', Christopher Brunner wrote:

'Today it is no longer possible for a country with any claim to industrial pre-eminence to attempt to stem the rising tide of oil and return to the low-water level of an earlier and less efficient age.'

(Brunner, 1931, pg. 9).

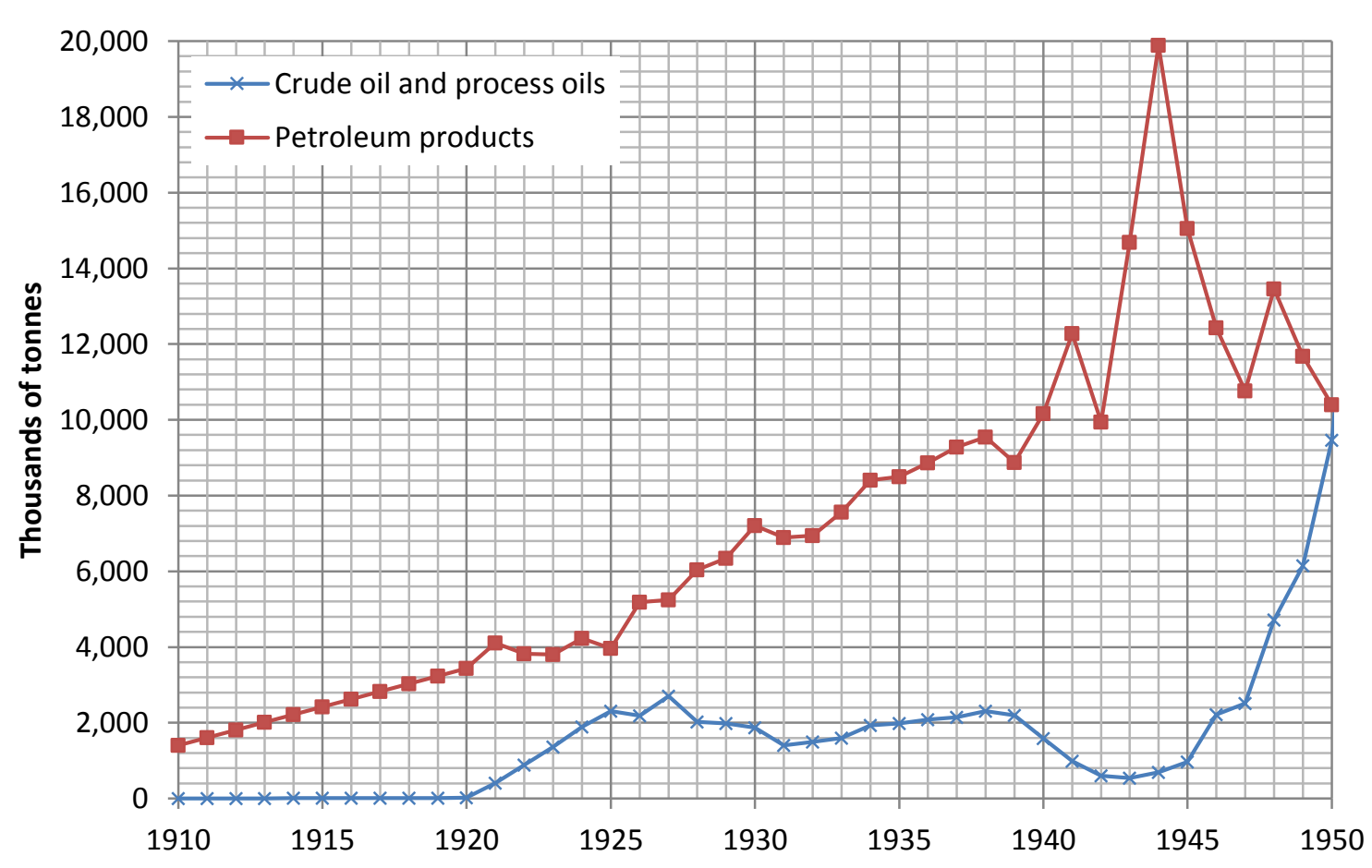

Figure 3: Imports of crude oil and petroleum products, 1910-1950, in thousands of tonnes (DECC, 2013) 
WWI helped transform the motor industry, stimulating the growth of private motor vehicles, public transport, and road haulage (Figure 4). This was primarily a legacy of military demand for vehicles which stimulated both production and technological development of the internal combustion engine (ICE) (Scott, 2002). Before WWI, the ICE was still at an experimental stage for motorised road haulage and could not compete with the rail networks over long distances. After WWI, the War Disposals Committee sold around 60,000 lorries and vans at low prices, while wartime duties had trained men and women to drive them (Scott, 2002). Furthermore, the rail strike in September 1919 highlighted the benefits and possibilities to firms of owning their own means of transport, further stimulating growth in this sector (Brunner, 1931). Figure 5 shows the rapid growth in tonnage transported by road haulage between 1921 and 1939, and also the rising share of total freight transported.

The inter-war period can be characterised as the second stage of diffusion of the private motor vehicle. Before WWI, production volumes were low; vehicles were expensive and were a luxury commodity, with ownership confined to the wealthy elite (Bowden and Turner, 1993). But between 1918 and 1939, car ownership grew 20-fold from just 100,000 cars to over 2 million in 1939 (Gardiner, 2010). Unit prices for motorcars also fell during this period. In 1936 an average car cost almost half what it had done in 1924 (Richardson, 1961). By 1937, over half a million cars a year were manufactured from factories clustered around Birmingham, Coventry, Luton, Oxford, and Dagenham (Gardiner, 2010). Although car ownership did not assume the mass-market proportions observed in the United States (Flink, 1998), growth was rapid.

Civil aviation, also benefiting from innovation during WWI, saw rapid growth during the inter-war period. By 1930, the aggregate mileage flown by air passengers and freight had grown 30-fold, increasing from 2.25 million in 1920 to over 69 million (See Figure 4, secondary axis; Cadman, 1931).

\subsection{Energy security during the inter-war period}

Concerns about energy security were voiced in the first decade of the 1900 s when a decision was made to change the entire Royal Navy fleet's fuel from coal to oil (Jones, 1981). With few domestic crude oil resources, energy security in Britain before and during WWI was primarily framed in terms of securing supply at reasonable prices for the British Armed Forces during wartime (Payton-Smith, 1971). A secondary concern, however, was the monopolistic organisation of the oil industry and the significant market power it held (Royal Commission on Fuels and Engines, 1913; Jones, 1981).

In order to guarantee supplies of fuel oil to the Admiralty, in 1914 the state negotiated a controlling interest in the Anglo-Persian Oil Company (APOC). The agreement stipulated that APOC supply the Admiralty with oil below market price and, during war, the Admiralty would have rights over the entire output. During a time of strong laissez-faire ideology, this level of involvement in a private firm was unprecedented. While the state had a controlling interest in APOC it did not participate in management activities. The decision to take a controlling interest coincided with an official recognition of fuel oil by the state as a, 'special article[s] of warlike material', exempt from the normal forces of the market (Jones, 1981, p.24).

During the inter-war period, experience from WWI shifted state perspectives on energy security to focus on scarcity and sovereignty, framed in economic or militaristic terms. First, disruption to Britain's oil supply chains during WWI from a German U-boat campaign in the North Atlantic heightened concerns about resource sovereignty throughout the inter-war period. Second, fears over oil scarcity grew during the 1920s. For example, in 1919, the director of the United States Bureau of Mines predicted that,

"...within the next two to five years the oil fields of this country will reach their maximum production, and from that time on we will face an ever increasing decline." (Yergin, 1999: 178). 
Concerns about absolute petroleum scarcity reached a climax after the 1926 publication of a pessimistic report by US President Coolidge's Federal Oil Conservation Board (Federal Oil Conservation Board, 1926). Because America dominated the world market at that time, the report reinforced the perceived need for government support of domestic motor fuel production (Figure 6). A 1929 report from the UK Department of Scientific and Industrial Research (DSIR) to the Oil Fuel Board, for example, argued that during war time, domestic, non-petroleum fuels were an attractive proposition, highlighting the benefit in terms of security of supply (DSIR, 1929).

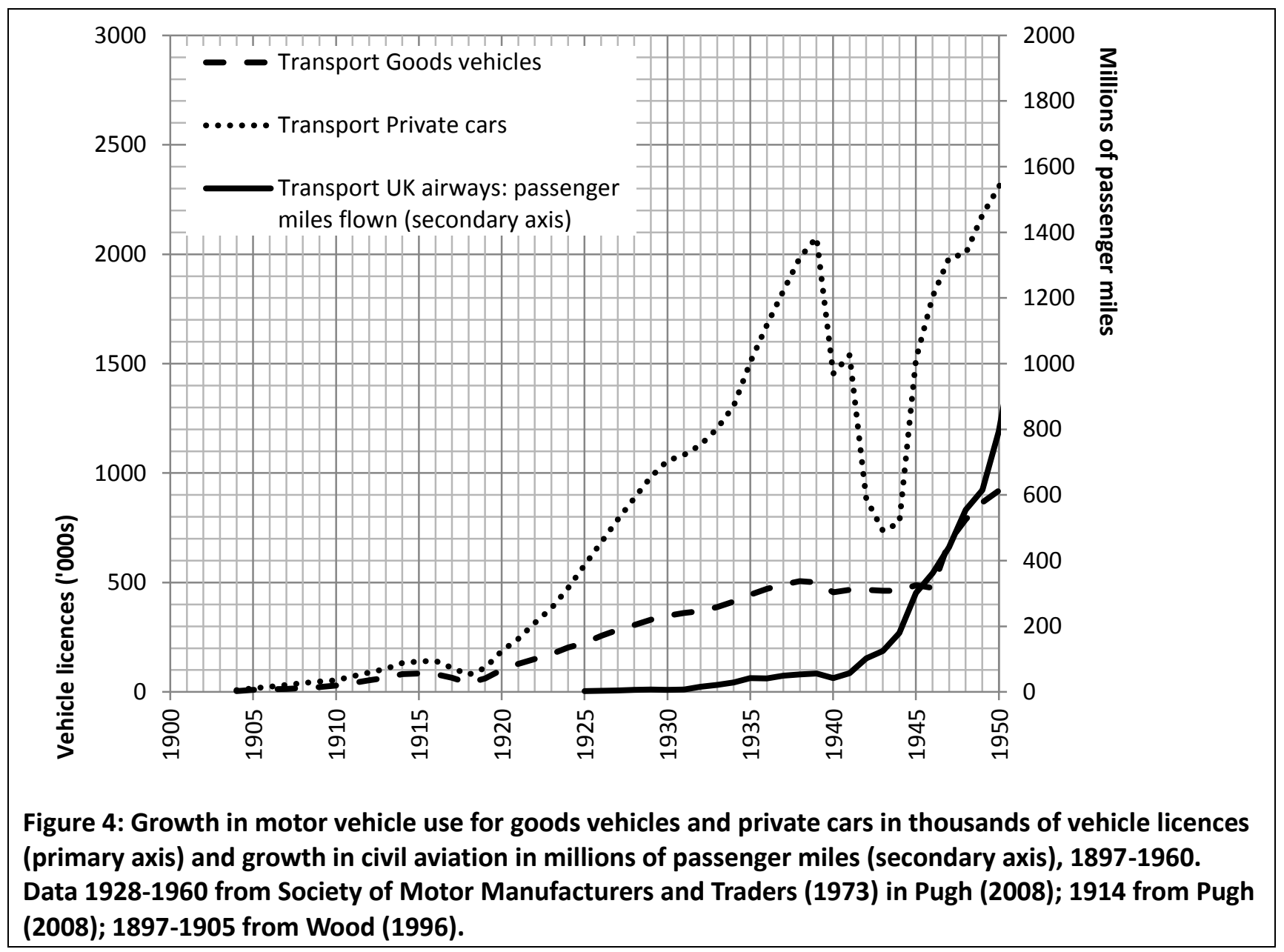




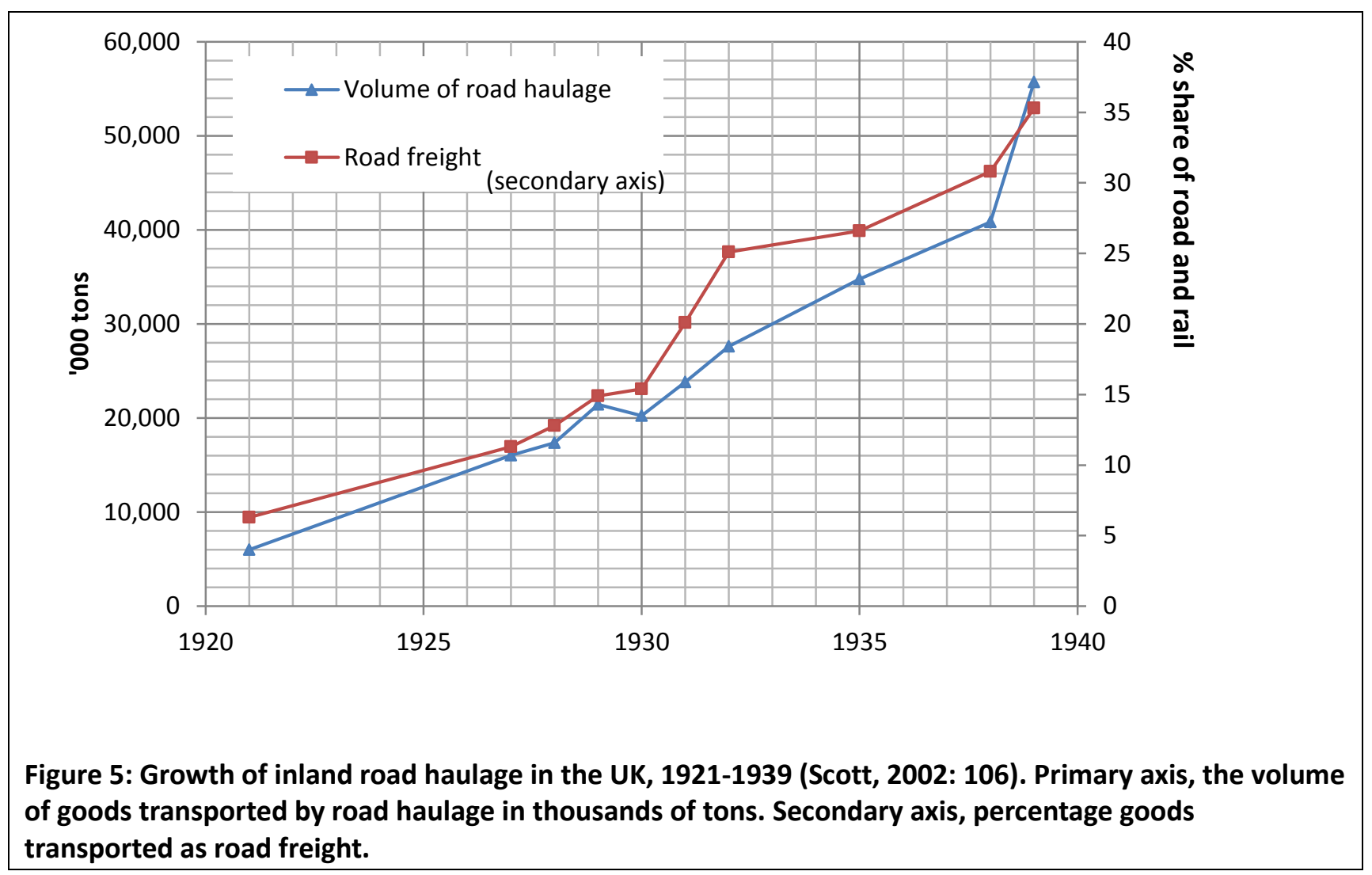

In the immediate years after the Federal Oil Conservation Board report, however, new oil was found in the US and elsewhere. The number of producing oil wells almost tripled, from 3,612 in 1932 to 9,372 in 1933, with production increasing from 1.2 million barrels to 171.8 billion barrels (Williamson, 1963). The consequent drop in oil prices was then exacerbated by falling oil demand during the global depression of 1929-1931.

Nevertheless, while oil did not now appear to be in short supply, Britain experienced two 'oil shocks'. The first 'shock' was triggered by a rise in oil prices due to restriction of supply by the oil majors in 1932, in response to the downward pressures on prices during the depression (Reader, 1977; Stranges, 1984). The second 'shock' was triggered by the collapse of the D'Arcy concession in 1933; this was a controversial 60year agreement between Iran and APOC made in 1909, which granted exclusive oil exploration rights to APOC in a particular area of Iran (Oil Fuel Board, 1933; Kakhki, 2008). After hurried negotiations a new agreement was reached. Nevertheless, the experience brought into relief Britain's dependence on foreign oil.

State, business, and civil society concerns about the significant market power held by the oil industry, however, never disappeared during the inter-war years. In 1920, for example, the Report on Motor Fuels, an inquiry into high fuel prices, argued that the oil industry operating at the domestic and international levels had too much market power and this threatened energy security. The report then urged the Government to develop a mechanism for controlling the oil industry's market power through the recently formed League of Nations, but concluded that domestic production of motor spirits, specifically power alcohol, was ultimately the only way to deal with fuel security (Report on Motor Fuel, 1920). While the state was acutely aware of the restrictive market structure created by the oil cartel, the industry, unlike in the US, remained unregulated for the duration of the inter-war period.

The origins and nature of the oil majors are important for the context in which power alcohol and petrolfrom-coal emerged. The conditions under which the multi-national oil company emerged in the twentieth century are well documented and not repeated here (see: Payton-Smith, 1971; Jones 1981; Macbeth, 1985; 
Nowell, 1994; Bamberg, 1994; Yergin, 2000). In summary, high capital costs of oil distribution and refining infrastructure led to the emergence of 'vertically integrated' firms with global interests in exploration, drilling, production, refining, shipping, distribution, marketing, and related services. In particular, capital intensive distribution networks and associated marketing expertise operated loosely as a 'natural monopoly'. Further, the small number of firms controlling the majority of the world's oil resources was conducive to cartelisation and the exercise of market power.

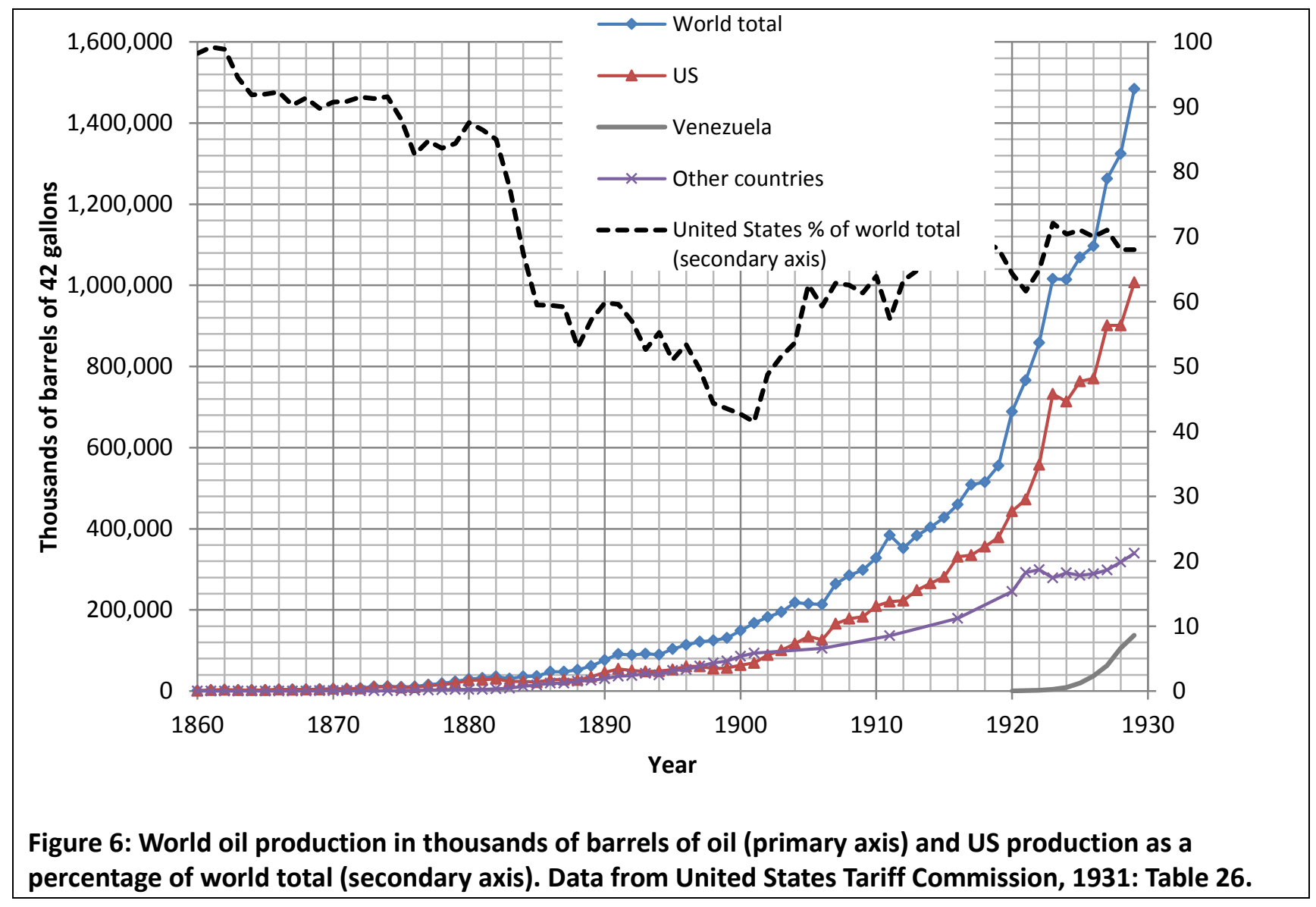

Market-sharing arrangements existed at the international level. Whilst in regular communication with one another during the inter-war years, the oil majors loosely cartelised in 1928. The agreement known as the 'As is' or Achnacarry Castle Agreement laid down the basis for an Anglo-Persian, Royal Dutch, and Standard Oil cartel focussed on controlling both supply and price. The agreement was strengthened and became more inclusive in succeeding years, particularly following the collapse of oil prices during the economic crisis of 1929-31 (Bamberg, 1994; Nowell, 1994).

In Britain, a decade of fierce price competition between distribution units of the oil majors, coupled to growing public anger at price volatility, led to the formation and wider political support for a 'Combine' in the 1920s (Brunner, 1930). The Combine sought to control wholesale and retail prices of motor spirit. It also placed restrictions on which retailers were permitted to sell its members' motor spirit: retailers had to be bona fide and approved by the Motor Agents Association. Whilst limiting competition and new market entrants, the agreement also sought to prevent adulteration of The Combine member's motor spirit with other, often lower grade fuels, or the adoption of other price cutting strategies by 'rogue' retailers and independent producers (Brunner, 1930; Dixon, 1963).

Following the widespread adoption of the petrol pump, from 1920, oil majors were able to wield even more control over the emerging distribution infrastructure. Before WWI, petrol and other fuels had been 
distributed in two-gallon tins. Restrictions on storage due to safety concerns meant retailers were limited to stocking a few tins, often from a variety of producers (Weir, 1995). As demand for motor spirit grew the inefficient system inflated distribution costs, reduced profit margins, and stimulated the development and use of the petrol pump. While the pump had high upfront capital costs, it reduced the cost of distribution significantly, making it an attractive commercial investment. Moreover, Combine firms either leased or provided finance for the petrol pumps to approved retailers. Coinciding with a relaxation of regulations on petrol storage, The Combine used the pump to coerce retailers into long-term contracts which stipulated that they could only distribute their brand of motor spirit (Brunner, 1930; Dixon, 1963). By the mid-1920s, The Combine dominated $85 \%$ of the market (Fitzgerald, 1927).

Increasing societal use of the motor car, sovereignty over petroleum resources and scarcity of supply were key drivers for discussions about direct support for domestic motor spirit production (Oil Fuel Board, 19251939. The oil industry at the international and domestic level was left unregulated. State interest in security of supply of liquid fuels, instead, prevailed through its controlling interest in APOC and the Oil Fuel Board, a sub-committee of the Imperial Defence Committee.

\subsection{Macroeconomic context}

The economic downturns Britain encountered during the inter-war years (Figure 7) led to high levels of unemployment (Figure 8) and exacerbated the already fragile labour relations that had existed before WWI. The social and economic depression of inter-war Britain, however, was not spatially homogeneous and was largely expressed in 'traditional industrial districts' (Linehan, 2003). These regions had a high dependence on traditional industries such as coal, textiles, shipbuilding and steel and their prosperity was heavily dependent on export markets (Greaves, 2005). During the 1920s, unemployment fell in London, the South East, and South West, and grew notably in the North East and Wales (Jones, 1981) (Figure 8).These conditions led to social unrest such as the Hunger Marches between 1922 and 1935 (Turnbull, 1973), General Strikes of 1921 and 1926 and the seven-month coal stoppage that followed the 1926 General Strike.

Many have attempted to understand the causes of Britain's' 'industrial decline'. We do not elaborate on the different perspectives. Instead, the reader is directed to Dintenfass (1999) and Edgerton (1996) for a thorough review of contrasting perspectives. Both authors have, however, argued that the view of a British industrial decline is too simplistic. Whether or not Britain was indeed at the start of an industrial decline, however, change was afoot. During the inter-war period, growing international competition shrank export markets for Britain's traditional industries, and the economic downturns destroyed demand and purchasing power within the Empire and other major trade partners. The economic downturns also led to growth in economic nationalism across Europe, resulting in trade restrictions, further exacerbating the economic slump.

The wartime economy and economic volatility during the inter-war years also led to a number of shifts in dominant economic ideology. For example, during WWI the transition in economic ideology changed from hard-line laissez-faire traditions to acceptance of greater state intervention. ${ }^{5}$

\footnotetext{
${ }^{5}$ A summary of changes in economic ideology over the study period can be described as: 1900-1914 (rationalisation, domestic cartelisation); $1914-$ 1918 (war economy, increased state intervention, identification of strategic industries); 1919-1928 (attempt to return to laissez-faire, but strategic industries still 'protected', rise of government supported research (i.e. Committee of Civil Research/ DSIR/ Fuel Research Board), continued rationalisation, international cartels); 1929-1935 (economic depression, growing support for planning, economic nationalism); 1935-1945 (rearmament, war economy); 1945-1958 (post-war reconstruction, nationalisation, welfare state, decline in synthetic fuels)
} 
Against this background, Government was under increasing pressure to address Britain's economic predicaments. The Committee for Civil Research (renamed the Economic Advisory Committee from 1931) was formed as a cross-departmental group that could flexibly respond to the challenges of economic recovery in post-war Britain (Macleod and Andrews, 1969). Political parties, economists, and social movements all devised long-term plans to support recovery, such as the Next Five Years Group (Marwick, 1964) and the Liberal Industrial Inquiry (Liberal Party, 1928). The Great Depression stimulated a second wave of proposals for economic recovery and a more planned approach to economic policy, such as Max Nicholson's seminal essay, 'A National Plan for Great Britain' (Nicholson, 1931), which led to the formation of the British think tank Political and Economic Planning (now the Policy Studies Institute) and 'Labour's Plan for Oil from Coal' (Labour Party, 1938).

Despite a rapid return to free-trade ideals following WWI, government continued to support industries that had been strategically important during the war. Furthermore, the experience of the wartime economy changed perspectives on the virtues of cooperation, mergers, and large-scale enterprise (Hannah, 1983).

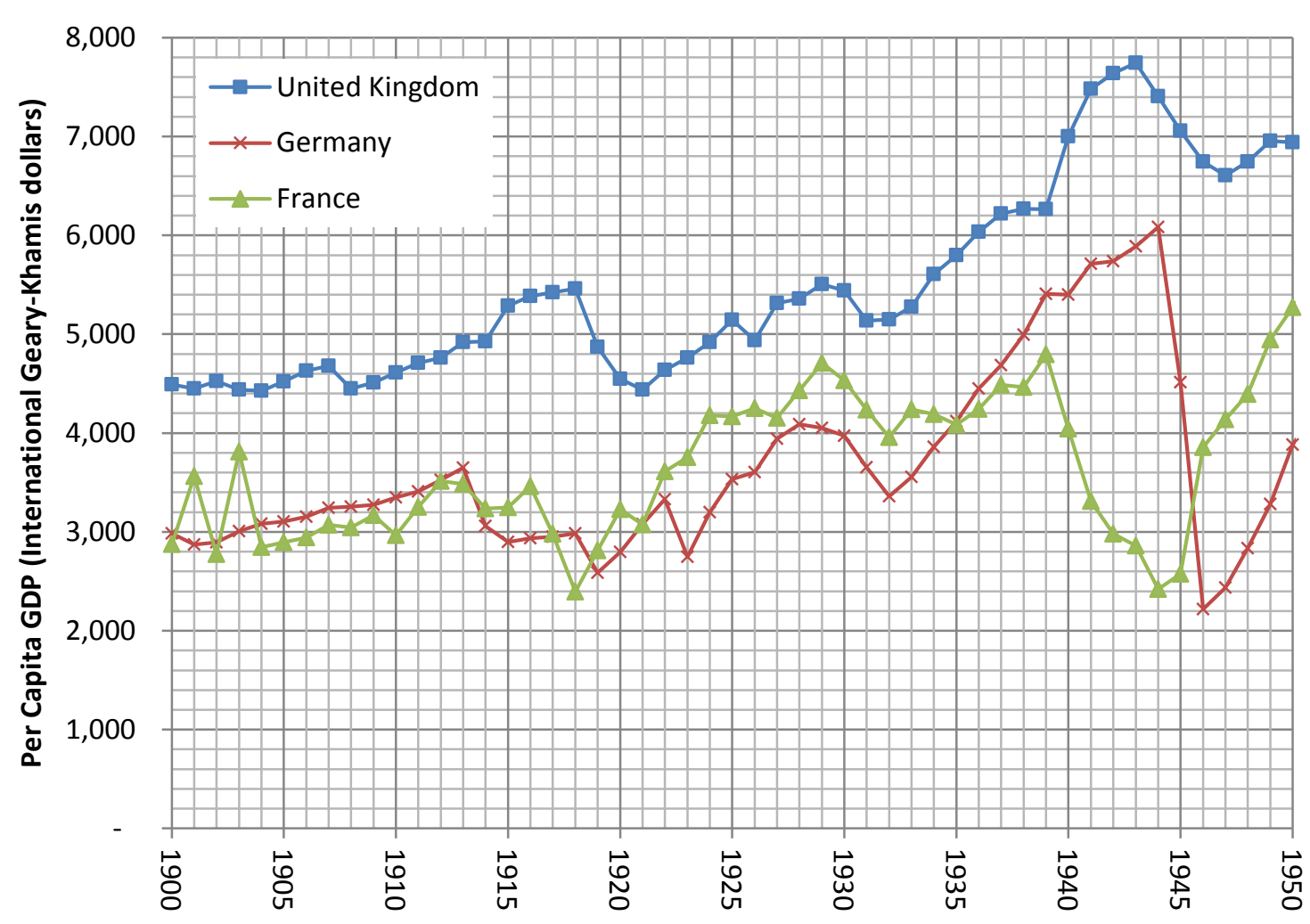

Figure 7: Per capita GDP in International Geary-Khamis dollars for United Kingdom, Germany and France, 1870-1969 (Maddison, 2003) 


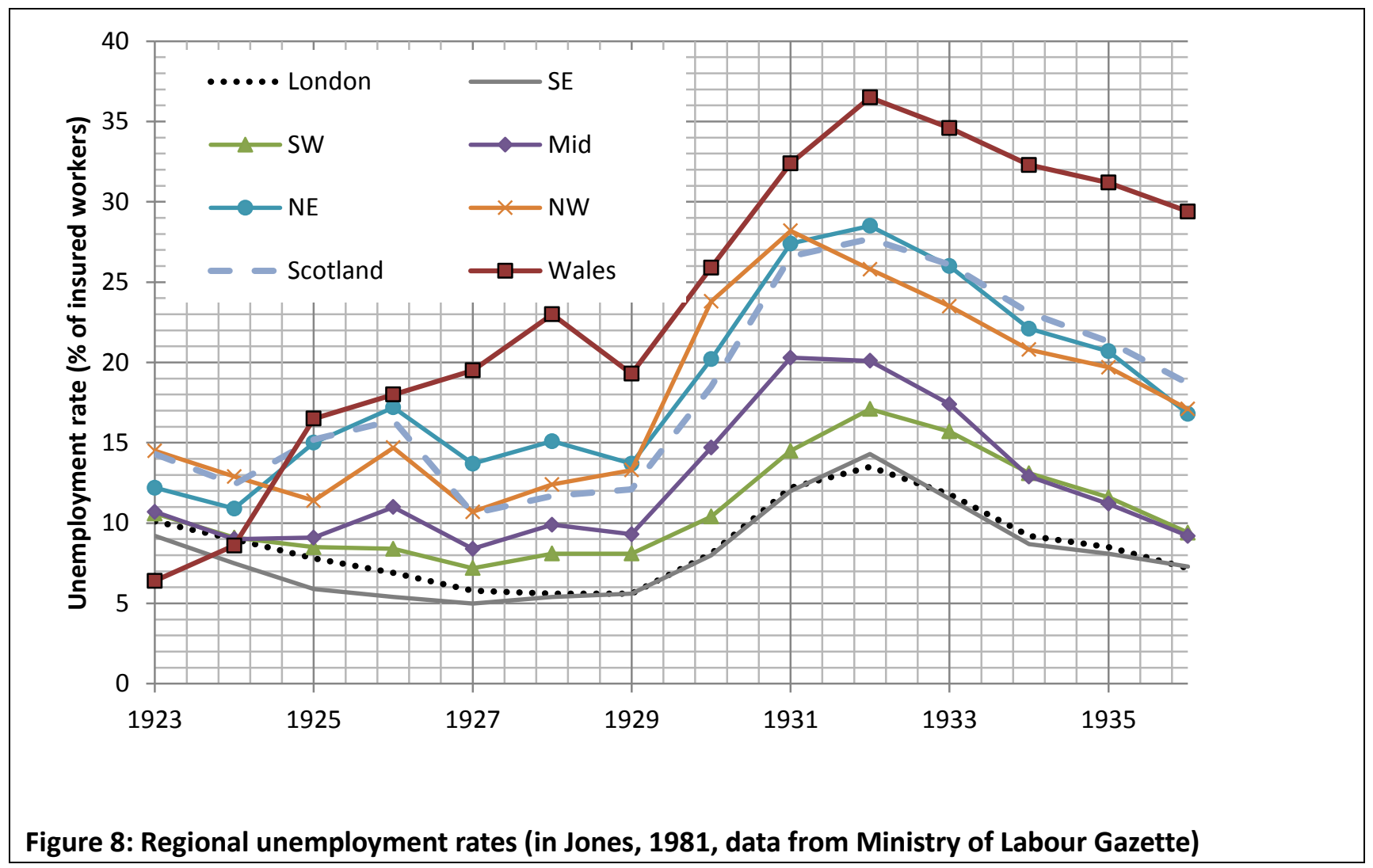

\subsection{The amalgamation movement}

Both $\mathrm{ICl}$ and DCL can be considered as products of the Second Industrial Revolution (the late 1800s and early 1900s) (Mokyr, 1998). Towards the end of the $19^{\text {th }}$ century and early $20^{\text {th }}$ century, industries were driven by the need to find new methods of raising capital in order to invest in increasingly technologically advanced equipment which would enable economies of scale to be realised. A key method of raising new capital was through amalgamation (Hannah, 1983).

Economies of scale offered a competitive advantage to growing international competition in Britain's key export markets (Greaves, 2005). In some instances, however, the rapid scaling-up led to overproduction. This fuelled a search for new markets for increased manufacturing capacity, but also an increase in cartels to control prices. Amalgamation also led to changes in organisational structure, as firms grew from small, family-run enterprises to large multi-site corporations that required professional managers.

During the inter-war period, the state encouraged amalgamation, particularly the Baldwin government of 1924-29, with official support given to mergers, cartels, and restrictive agreements (Broadberry, 1986; Richardson, 1961). According to Broadberry (1986: 115) 'These benefits were regarded as offsetting potential welfare losses of monopoly', and this view was reflected in the Balfour Committee reports of 1927 that had looked into the state of Britain's industrial sectors. Given this, the number of firms disappearing to mergers in the 1920s-30s was 230 per cent greater than in the first two decades of the $20^{\text {th }}$ century (Hannah, 1983).

Throughout the inter-war years, radical change in the transport sector had an impact on government thinking about how sufficient quantities of imported fuels were to be supplied. The economic downturns during the inter-war period and the widening trade deficit (partly due to economic nationalism across 
Europe) and rising demand for imported petroleum, drew attention to domestic production of alternative liquid fuels. WWI had highlighted the vulnerability of relying on international oil supply chains and the strategic importance of liquid fuels. Consequently, the multi-faceted concept of energy security was a key concern. This concern contributed to providing the impetus for research into, and support for, the domestic production of motor fuel. As such, the potential to develop substitute fuels by British industry, and in the case of coal hydrogenation to support the struggling coal industry, were viewed by many as a panacea to Britain's modernisation, economic prosperity and militaristic needs.

\section{Power alcohol (DCL)}

Power alcohol was non-potable alcohol, 'for use as motor fuel, either on its own or as a constituent in a blend' (Weir, 1995, p.287). Power alcohol differed from petrol in that it possessed, 'anti-knock' ${ }^{6}$ qualities. Knock, in an internal combustion engine, is an undesirable sound caused by premature combustion of the fuel and air mixture in the cylinder of an engine. Power alcohol did not cause knock in engines as it had a higher octane rating than petrol, making it suitable for high-compression engines (often found in commercial vehicles, sports, and motor-racing cars). It offered improved engine power, increased mileage, and lower running costs than petrol (Commercial Motor Archive, 1923).

The alcohol used in power alcohol was produced by the Distillers Company Limited (DCL). An extensive business history of DCL has been written by Weir (1995), from which some detail of the power alcohol story derives. Bernton et al. (2011) have written an in-depth history of alcohol fuels around the world, describing the current and historical situation in the UK whilst focusing on America. Archival documents from various government committees (1919 Committee; May Committee, 1944/45) have also informed this history of power alcohol.

DCL formed in 1877 as an amalgamation of several Scottish whisky distilleries. It grew to become one of the largest distilling companies in the UK, and with it a powerful force in the UK's distilling industry. DCL developed into a vertically integrated company with a hand in most things concerning the distiller; from the supply of raw materials to the quantities of alcohol to be produced by smaller distillers in the UK. Technological change spurred early attempts to control the market for alcohol. The key technology was the Coffey, or patent, still. Patented in 1830 by an Irish distiller, Aeneas Coffey, the patent still could produce a relatively pure and concentrated spirit in large quantities, in contrast to the traditional pot still (Weir, 1995). It used a variety of feedstocks, mostly unmalted cereals and molasses, to produce grain alcohol, whereas the pot still used only malted barley for the production of malt whisky. Furthermore, patent stills used a process of continuous distillation (as opposed to the traditional pot still which required emptying before subsequent distillations could take place) meaning that larger quantities could be produced more quickly. For DCL, adoption of the patent still and the production of large quantities of alcohol enabled the development of new markets, one of which was power alcohol.

DCL recognised the need for diversification following a sharp decline in the whisky market around 1890 and, around 1905, moved into a new market producing alcohol for industrial purposes. (Although power alcohol was a different product to industrial alcohol, it was strongly influenced by decisions made by government on industrial alcohol.) Home produced alcohol for industrial purposes was seen by many users as too expensive compared to the same product imported from Germany and America (1905 Committee). The high cost of domestic industrial alcohol was attributed to the Excise duties imposed on it. It was argued

\footnotetext{
${ }^{6}$ Knock, in an engine, is also called 'pinking', said to mimic the double, 'pink pink' call of the Chaffinch (Oxford English Dictionary, $3^{\text {rd }}$ Edition, 2006; Bernton et al., 2010).
} 
that for industrial alcohol to be competitive with imported industrial alcohol, changes to the duties would be required. Distillers and chemical manufacturers were not alone in calling for changes: farmers sought government support for home-grown produce; the motor industry claimed that a reduction in the cost of alcohol would provide an alternative to petrol (the market for which was thought to be controlled by the three oil companies who supplied petrol); and the Liberals' argued that the government was neglecting 'science-based industries' (Weir, 1995, p.288).

An Inter-Departmental Committee on Industrial Alcohol (1905) deemed that the 'vital importance' of the scientific side of the chemical industry had been previously overlooked. It recommended a subsidy for industrial alcohol, rationalised as an, 'inconvenience bounty' of $3 d$. per proof gallon ${ }^{7}(\mathrm{ppg})$ which was accepted by government and introduced in 1906. The 'inconvenience' experienced by distillers arose from Excise restrictions. These included the prevention of simultaneous brewing and distilling, meaning that brewing and distilling processes had to be conducted sequentially, preventing continuous production from being carried out. Furthermore, no brewing, fermentation, or distillation could be carried out on a Sunday. Both restrictions were considered by the Committee as restricting output and contributing to the higher cost of industrial alcohol (1905 Committee). The bounty was seen as a means of making alcohol cheaper and therefore more available to the chemical industry. The Committee did consider power alcohol for motor vehicles but concluded it to be uncompetitive against the cost of petrol at the time. Nevertheless, the bounty had the effect of making alcohol, 'the cheapest raw material for the organic chemical industry during the inter-war period' (Weir, 1995, p.289).

By 1913, with the rapid increase in car ownership and demand for fuel, petrol prices had risen, narrowing the gap between alcohol and petrol prices. Furthermore, concerns were rising over the reliance on foreign oil and suspicions over petrol price-fixing by the oil companies (The Times, 1913). After WWI, which had exposed Britain's dependency on foreign oil (Jones, 1981), another Inter-Departmental Committee was convened in 1919.

This 'Inter-Departmental Committee on various matters concerning the production and utilization of alcohol for power and traction purposes' 8 looked to Germany to learn from their power alcohol industry. Germany had developed a thriving power alcohol industry using potatoes as a raw material. Production in Germany was carried out by small, often farm-based distilleries to supply fuel for agricultural, and other, vehicles. The Committee recognised that, unlike petrol, the chief raw materials for alcohol (primarily molasses) were cheaply available within the Empire. Furthermore, they noted that the raw materials 'can be renewable and are susceptible of great expansion' (1919 Committee, 1919, p.7) whilst petroleum products, 'are limited to deposits, definite in extent, that cannot be renewed' (op. cit.). The report goes on to state,

'as power alcohol is miscible with water in all proportions, its use affords greater safety from fire than does the employment of benzol, petrol or other petroleum products. We consider that these two factors [availability and safety] should be regarded as sufficient grounds in themselves to justify State action in fostering the production and utilisation of alcohol for power purposes' (op. cit., p.7)

Both home-produced benzol (derived from coal) and shale-oil (from Scottish shale) motor-spirits were exempt from taxes at the time of the 1919 Committee. The report recommended that home-produced power alcohol be subject to the same tax exemptions and that the inconvenience allowance on industrial alcohol be extended to power alcohol. Power alcohol therefore benefitted from both tax exemption and financial support through the bounty. Reflecting on the potential for large quantities of power alcohol to be produced in the colonies, the Committee recommended that imported power alcohol from the Empire also

\footnotetext{
${ }^{7}$ Pre-decimal currency: $d$ (pence, 240 per $f 1$ ); s (shilling, 20 per $f 1$ ).

${ }^{8}$ Chaired by Sir Boverton Redwood.
} 
be duty free. Subsidies on the raw materials (specifically molasses) used in distilling power alcohol were also recommended for those countries within the British Empire to support growing protectionist attitudes towards home industry. The report, reflecting energy security concerns of the time, called for State action, rather than leaving it to the, 'chances of private enterprise, individual research and the ordinary play of economic forces', recommending that,

'an organisation should be established by the Government to initiate and supervise experimental and practical development work, at home and overseas ... the organisation should be permanent ... be in close relation with the various Governments of the Empire, and be so constituted as to be able to deal with alcohol in conjunction with other fuels which are or may become available as a source of power' (op. cit., p.8).

Government adopted the Committee's recommendations for extending and increasing the allowance, on the grounds that home industry required government protection against the powerful oil combine (Second Report on Motor Fuel, 1921).

Research and development (R\&D) into power alcohol was also carried out by DCL. Although R\&D investments were made, the technological developments they needed to produce the quality and quantity of power alcohol required for commercial purposes were actually achieved through the purchase of patents. The most suitable production method was judged to come from the US, via the 'Alcogas' patent. This was used to produce and market the 'Discol' power alcohol brand in August 1921. With the subsidy, it was claimed by DCL that Discol was cheaper than the cheapest petrol and also had, 'the advantage over petrol of increased power [and] equal mileage' (Weir, 1995, p.298).

Dispersed supply depots meant that DCL had difficulty establishing a broad customer base. However, depots attracted motor enthusiasts who liked Discol's superior characteristics over petrol. These characteristics eventually led DCL to produce PMS 2 Discol - a new motor racing fuel (Weir, 1995). DCL were keen to expand the market for Discol, by selling power alcohol to oil companies for blending. A first attempt to blend alcohol with petrol and benzole through the National Benzole Association failed, as the oil company supplying National Benzole refused to sell petrol for blending. However, in December $1933 \mathrm{DCL}$ secured a contract for bulk alcohol supply to the Cleveland Petroleum Company, who sold 'ClevelandDiscol' as a luxury fuel. During the late 1930s Esso bought into Cleveland and eventually obtained a controlling interest just after WWII (keeping the Cleveland-Discol brand).

Since 1924, however, doubts about the cost to the Treasury of the allowance, had periodically arisen (Marsden, 1943). Consecutive Chancellors of the Exchequer declined to address the issue until the end of WWII. Whilst the consumption of power alcohol had risen significantly since 1921, the production of industrial alcohol had risen even further and government was indeed losing significant revenue used for the allowance (op. cit. 1943). The May Committee (1944/45) was established to investigate. Finding that the original grounds on which the allowance had been granted were no longer applicable, and that support for industrial alcohol was impeding the development of synthetic processes (using oil rather than molasses to produce chemicals), the inconvenience allowance was withdrawn in 1945 (May Committee, 1945). The final decision to withdraw the allowance focused on industrial alcohol and overlooked, but included, power alcohol, thereby contributing to its demise. Cleveland-Discol, like many branded fuels, disappeared during WWII but reappeared again at the pumps until around 1973 when Esso removed it from sale. Power alcohol, originally intended by government to provide a reliable, domestic source of fuel, finally succumbed to the overwhelming dominance of oil, for fuel and as a raw material in the chemical industry.

The story of power alcohol illustrates how fluctuating concerns within government over fuel supply affected their thinking about, and action towards, a potential petrol substitute. Unable to affect the price of petrol, and under pressure to support home industry and address fuel security issues, the only option 
government judged appropriate was to provide a subsidy to make the production of power alcohol commercially viable. However, austerity measures taken following WWII, combined with greater certainty in petrol supplies, shifted thinking in government away from supporting power alcohol production and led to the removal of the subsidy. Without the subsidy it became more difficult for power alcohol to compete with petrol, particularly as production and sales of alcohol came within control of the oil companies.

\section{Petrol-from-coal (ICI)}

This section examines the circumstances under which state support was provided to ICl's petrol-from-coal programme during the second half of the inter-war period. Histories that detail the emergence of coal hydrogenation in the early $20^{\text {th }}$ century have been written from a number of different perspectives. Reader (1977), the most widely cited account of coal-hydrogenation in Britain, focuses on the development of the technology from ICl's perspective, using extensive company archives. Stranges (1984) presents a more technologically focussed history; it draws on Reader's analysis but is supplemented with material from academic literature and government archives, particularly documents from the DSIR. Kirk (1998) and Bennett \& Pearson (2009) turn their attention to the role of coal hydrogenation technology in the development and emergence of the petrochemical industry. Beyond Britain, Hughes (1969) and Stranges $(1985 ; 2000)$ focus on the early history of coal hydrogenation, the emergence and development of the technology in Germany and the role of German chemical combine IG Farbenindustrie (henceforth, IG Farben). Finally, Nowell (1994) examines the history of coal hydrogenation with specific reference to the oil majors and the International Hydrogenation Patents agreement (an international patent pool for coal hydrogenation founded in 1931) by drawing on the secondary literature identified above and evidence given before the Committee on Patents in the US in 1942.

This case study draws heavily on the sources identified above, but is supplemented with primary sources, to examine why and under what circumstances state support was provided for this technology, the actors involved and their roles in the emergence and evolution of coal hydrogenation during the inter-war years.

The Bergius process (also coal hydrogenation) developed by German chemist Friedrich Bergius, became a key method for producing a substitute to petroleum-derived motor fuels in Europe during the inter-war period (see Figure 1). Between 1927 and 1943, 12 coal hydrogenation plants were built in Germany, two in Britain and one in Korea. The construction of commercial-scale coal hydrogenation plant mostly occurred during the late 1930s when Germany and Britain began rearming and during WWII (National Academy of Sciences, 1977).

Developed alongside the Haber-Bosch process for ammonium production in Germany (Hughes, 1969; Smil, 2004), coal hydrogenation involved a reaction of hydrogen gas under high-pressure and temperature with creosote (coal-tar) or a creosote and a powdered coal mixture. This yielded a synthetic crude oil. Further distillation of the synthetic crude oil resulted in a variety of different hydrocarbon oils, and in particular petrol. The petrol was a high quality fuel that could be readily blended with petroleum-derived petrol for a high quality motor spirit (Oil Fuel Board, 1931) or tetra-ethyl lead and iso-octane for a high-octane aviation spirit (Reader, 1977).

\subsection{ICl and coal-hydrogenation}

ICl formed in late 1926 as an amalgamation of four of Britain's largest chemical firms - Nobel Industries Ltd., British Dyestuffs Corporation, Brunner, Mond \& Co. Ltd. (henceforth, Brunner) and United Alkali Company. ICl's formation was encouraged and brokered by Government officials, partly in response to chemical combines that had emerged in Germany and the United States. In particular, in 1925, Germany nationalised 
IG Farben - a consolidation of Bayer, BASF, Hoechst and five smaller German firms. The vision for ICI was that it would exploit growing and emerging markets within the Empire (Reader, 1977), particularly in the agricultural fertiliser sector. Government officials and industrialists also held the view that if Britain was to retain its position as industry leader and participate in international trade agreements in the strategically important chemical industries, Britain needed a firm that had the similar scale and scope to IG Farben (US Tariff Commission, 1937; Pettigrew, 1985; Reader, 1977).

The British government played a central role in the early stages of coal hydrogenation development in Britain, whilst ICl was central to the commercial development of the technology from the late 1920s and 1930s.

\subsection{The emergence of coal-hydrogenation in Britain}

Why did the government express such strong interest and eventual support for the commercialisation of coal hydrogenation, given that there were already a number of competing processes for coal-based liquid fuel production at various stages of development during the inter-war period (Falmouth Review, 1938; Labour Party, 1938; Egloff, 1938)?

First, other processes, apart from the Fischer-Tropsch process (also hydrocarbon synthesis), such as low and high-temperature carbonisation were by-product processes. The efficiency of conversion was low; production was limited by demand for the primary product - metallurgical coke and town gas (PaytonSmith, 1971). In and of itself, by-product motor spirits, while popular, were neither economical nor had the potential for large-scale production necessary to keep up with the rapid growth in demand. The FischerTropsch process developed in 1925 could produce a coal-petrol and did not need the expensive highpressure equipment required for coal hydrogenation. It was, however, at an earlier stage of development compared to coal hydrogenation, and the petrol produced was deemed to be of lower quality (Oil Fuel Board, 1932).

Second, support for coal hydrogenation in Britain was strongly linked to similarities between the Bergius process and the Haber-Bosch process of ammonia synthesis; specifically the high-pressure equipment and large-scale manufacture of hydrogen required.

Fixed nitrogen was a strategic material used in both the production of agriculture fertilisers and explosives. At the end of the $19^{\text {th }}$ century, there were only two major sources of fixed nitrogen, sodium nitrate from Chilean saltpetre deposits and ammonium sulphate, produced as a by-product of coal carbonisation (Haber, 1971). Nations were acutely aware that Chilean supplies were vulnerable to interruption during wartime, or to supply shocks from industry cartels. And, the nature of by-product ammonium sulphate meant that it was limited by demand for the primary product. This prompted a search for more efficient and large-scale production methods of fixed nitrogen at the turn of the $20^{\text {th }}$ century (Haber, 1971; Hughes, 1969).

A number of competing processes for nitrogen production emerged at the same time. The Haber-Bosch process developed by German chemical firm BASF and later IG Farben, however, could produce fixed nitrogen on an industrial-scale without the large quantities of electricity needed by the other processes (Haber, 1971; Hughes, 1969). Despite high upfront capital costs, the potential for large-scale low cost production meant the Haber-Bosch process was the most economically attractive option. During WWI, Germany rapidly developed Haber-Bosch plant, generating widespread international interest. This was due, in part, to the strategic importance of fixed nitrogen, but also the technological prowess associated with the high-pressure and high-temperature engineering involved (Hughes, 1969; Lamer, 1957).

Ammunition shortages in 1915 prompted the UK Ministry of Munitions to the establish the Nitrogen Products Committee which proposed the construction of a $£ 5$ million (nominal) Haber-Bosch plant at 
Billingham, Stockton-On-Tees (Lamer, 1957). By the time the war ended in 1918, however, only preparatory work had been achieved due to a downgrading of its priority grade (Haber, 1986) and severe technical difficulties. Germany had kept details of the Haber-Bosch process shrouded in secrecy. It was only with post-WWI patent sharing and state sponsored visits in 1920 to similar German plant that Britain gleaned the intelligence necessary to complete the plant (Parke, 1957). Despite the end of hostilities, the Ministry of Munitions continued to develop the large-scale Haber-Bosch plant at the Billingham site; however, the focus switched from explosive manufacture to fertiliser production.

The return to more free-market ideology after the period of state intervention during the war, however, led to a rapid selling off of state-owned production facilities, including the Billingham site. After a quasi-closed process of tender, and the collapse of several syndicates, Brunner purchased it through its subsidiary Synthetic Ammonia \& Nitrates Ltd. in 1920 (Parke, 1957; Reader, 1977; Pettigrew, 1985). Following the successful operation of a pilot plant at Brunner's site in Runcorn, Cheshire, the first commercial-scale plant, then the largest in the world, was opened at Billingham in 1923 (Haber, 1971; Parke, 1957).

Between 1925 and 1926, and shortly before its amalgamation into $\mathrm{ICl}$, Brunner invested a further $f 3$ million, at the urging of the British government, into an even bigger ammonia plant at Billingham (Haber, 1971). In 1927, ICl's board decided to sanction further capital expenditure on the Billingham site, tripling the production capacity at Billingham and bringing the total expenditure to $f 20$ million (Beynon et al., 1994). Soon after the opening of the new capacity in 1928 the economic crisis of 1929 led to a dramatic fall in demand for nitrogen fertiliser products. This occurred against a backdrop of an already saturated global nitrogen fertiliser market in which prices had been falling for at least the previous two years (see Figure 9).

By 1929 there was 50 per cent overcapacity at Billingham, the plants were running at a loss and the return on capital employed had dropped below 5 per cent (Pettigrew, 1985). The new combine was left with expensive, under-utilised high-pressure equipment. Whilst ICl's other divisions fared better during the economic crisis, protecting it from insolvency (Pearcy, 2002), media speculation led to the collapse of its share price by a third from 33s 6d in 1929 to just 9s 10.5d in 1931 (Reader, 1977). ICl was under pressure from shareholders to identify new markets for its stranded assets at Billingham.

ICl's existing knowledge base in coal hydrogenation due Brunner's early involvement in coal hydrogenation meant that developing coal hydrogenation at Billingham offered $\mathrm{ICl}$ a new market for their high capital equipment. Against the backdrop of growing concerns regarding fuel security and development of domestic fuel production, ICl built on its existing knowledge base and began to lobby for state support for a commercial-scale plant at the Billingham site. 


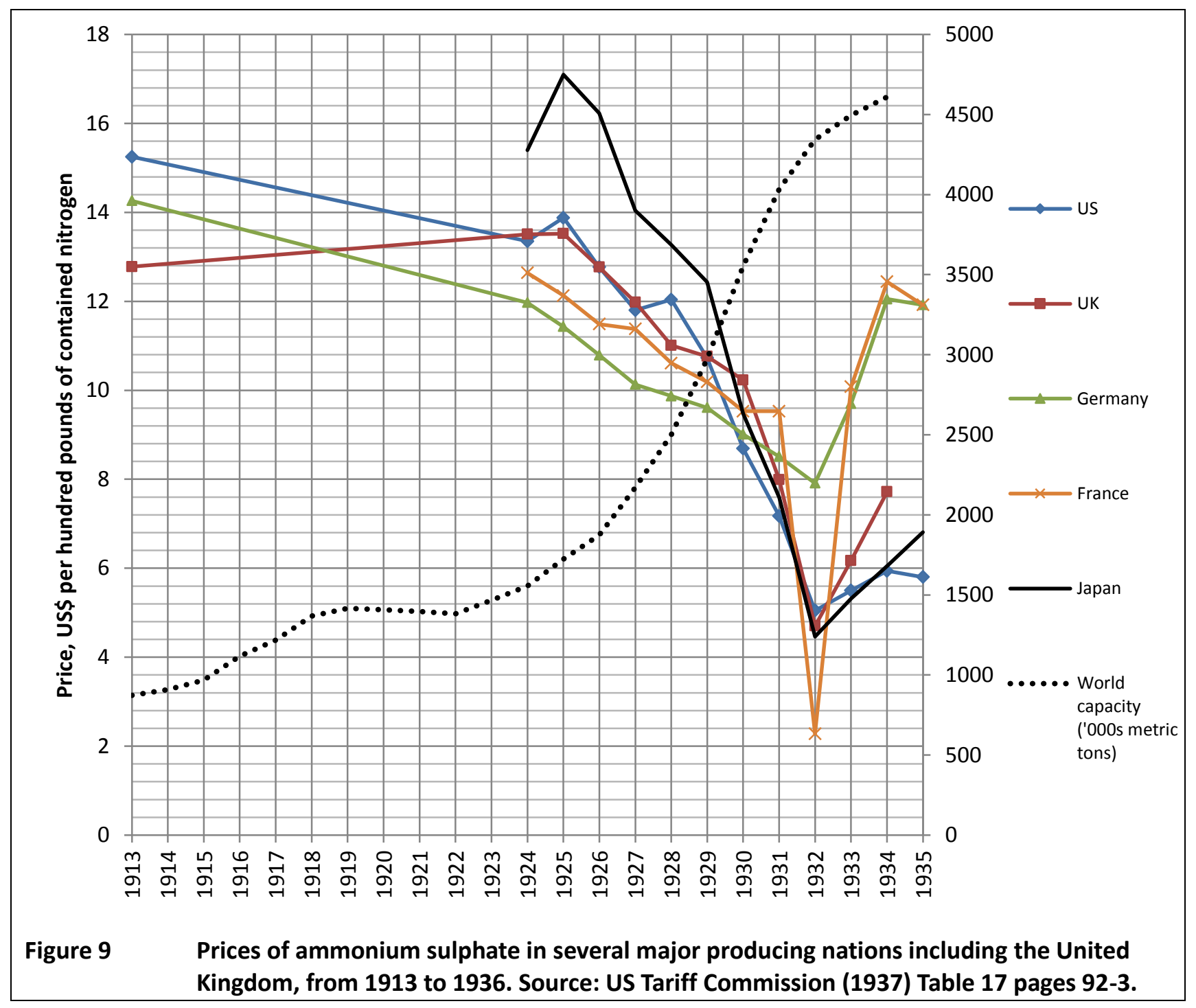

\subsection{State support for coal hydrogenation}

Early state support for coal hydrogenation began in Britain between 1920 and 1926 and was primarily undertaken by the DSIR in the following ways: i) grants to the British Colliery Owner's Research Association, which then funded coal hydrogenation research at the University of Birmingham; ii) finance to the British Bergius Syndicate (BBS), a group of 15 investors including Brunner for the acquisition of Bergius patents and research into hydrogenation of British coals at the German Bergius Research Institute, and iii) research at the Fuel Research Station in Greenwich (Stranges, 1984).

From 1927 until 1939, while the Fuel Research Station continued to perform basic research and "scientific study" of the Bergius process, ICl proceeded with its commercial development (DSIR, 1929) at the encouragement of government, specifically the Oil Fuel Board of the Committee of Imperial Defence and the Treatment of Coal Sub-Committee, a sub-committee established in 1929 (Reader, 1977; Oil Fuel Board, 1926-1939). In 1928, ICl also agreed to provide regular updates to the Oil Fuel Board regarding developments (Oil Fuel Board, 1928). 
Between 1927 and 1930, ICl spent $f 325,000$ (nominal) researching coal hydrogenation. By 1929 it was in the position to install a pilot plant that could hydrogenate 10 metric tons of coal a day (Reader, 1977; Stranges, 1997). The aim was to establish whether production of petrol-from-coal could be carried out economically. As soon as $\mathrm{ICI}$ had completed its commercial development, it also hoped to sell the technology to the oil majors (CAB 50/3 359).

At first ICl was optimistic that large-scale production could produce a petrol that would be price competitive with imported petrol, even though the profitability of the operation would be small. In 1929 the price of imported petrol was $6.5 d$ per gallon. With inland distribution costs and duties the wholesale price amounted to $1 s 2 d$. In contrast, $\mathrm{ICl}$ argued that petrol-from-coal could be produced at a cost of 6.5-9d per gallon (DSIR, 1929). Demand destruction caused by the economic crisis of 1929-31, however, led to the price collapse of oil. This reduced the economic viability of the enterprise without state subsidisation (Reader, 1977). Faced with losses from the under-utilised fertiliser plants at Billingham, however, and intimation by the Oil Fuel Board that it was interested in exploring commercialisation of coal hydrogenation within Britain and the Empire (Oil Fuel Board, 1929), by $1930 \mathrm{ICl}$ had drawn up plans for a commercial-scale plant. Initial cost estimates were $\mathrm{f} 9$ million (nominal) for a plant that could produce 210,000 tons of petrol a year at $8 d$ a gallon. This marked the beginning of a long, arduous process of negotiation between the Board of Trade and ICl that eventually led to the British Hydrogenation Oils Production Act, 1934.

Over a period of five years, $\mathrm{ICl}$ submitted proposals whilst the Board of Trade responded with counterproposals. ICl repeatedly argued that development of a large-scale commercial plant would increase national fuel security. Once the technology had been developed, plant could be built rapidly during an emergency. They also argued that the increase in demand for coal would create employment within the struggling coal industry, particularly in the North East, an area with one of the highest unemployment rates in the country (see Figure 8; DSIR, 1929). The Board of Trade responded that the proposals were not ambitious enough, capital could not be provided for plant construction, profit margins $\mathrm{ICl}$ were expecting were too high given the capital requested from the state and that they were exaggerating potential employment creation (Reader, 1977).

The two institutions developed a framework for cooperation over the five year period. But by 1932, ICI seriously considered pursuing their coal hydrogenation plans without confirmed state support. At that time, customs duty of $8 d$ on imported fuel, along with distribution and other costs, meant that petrol-from-coal was just price competitive with No.1 motor spirit. Any change to either of those factors, however, could have altered the situation. As such, $\mathrm{ICl}$ considered the risk too high and decided not to continue alone.

Two successive oil shocks, however, created renewed interest in domestic oil production. The first oil shock in 1932 was the result of oil major cartelisation in response to a fall in oil price (Stranges, 1984). The second was related to the collapse of the D'Arcy Agreement (Oil Fuel Board, 1933). The doubling of oil prices that followed made coal hydrogenation even more competitive. But the price volatility meant the project was still too risky for ICl to pursue alone. Given this, in 1933, ICl approached the Board of Trade with a proposal that requested a guarantee that domestic production of hydrocarbon oils would receive a tariff protection of no less than $8 d$ per gallon, the current import duty on light hydrocarbon oils. The Board of Trade agreed to the tariff protection, but stipulated a cap on profits from the enterprise of 5 per cent to quell any allegations of preference to ICI (Reader, 1977). ICI immediately began construction of a large coalhydrogenation plant at Billingham, capable of producing 100,000 tons of petrol from coal and coal tar. Soon after, planned capacity was increased to over 150,000 tons of oil with two-thirds from coal. While coal from the nearby Durham coalfields was initially planned to be the primary feedstock, by 1940 the plant had completely switched to creosote due to difficulties with handling a coal feedstock and the rising price of coal (Table 1; Stranges, 1984; Payton-Smith, 1971). 
Table 1 Petrol-from-coal output at Billingham, 1935-1945 (Stranges, 1984) and annual preference (author estimate)

\begin{tabular}{|c|c|c|c|c|c|}
\hline Year & $\begin{array}{l}\text { a Gallons of petrol-from- } \\
\text { coal produced from coal }\end{array}$ & $\begin{array}{l}{ }^{\text {a }} \text { Gallons of petrol-from -coal } \\
\text { produced from creosote }\end{array}$ & $\begin{array}{l}\text { Total production } \\
\text { (Gallons) }\end{array}$ & $\begin{array}{l}{ }^{\mathrm{b}} \text { Estim } \\
\text { to I }\end{array}$ & $\begin{array}{l}\text { ted preference } \\
\text { I (nominal) }\end{array}$ \\
\hline 1935 & $3,300,000$ & $17,400,000$ & $20,700,000$ & $f$ & 690,000 \\
\hline 1936 & $10,500,000$ & $22,800,000$ & $33,300,000$ & $f$ & $1,110,000$ \\
\hline 1937 & $13,200,000$ & $22,200,000$ & $35,400,000$ & $f$ & $1,180,000$ \\
\hline 1938 & $15,600,000$ & $27,300,000$ & $42,900,000$ & $f$ & $1,608,750$ \\
\hline 1939 & $8,400,000$ & $36,000,000$ & $44,400,000$ & $f$ & $1,665,000$ \\
\hline 1940 & - & $44,400,000$ & $44,400,000$ & $f$ & $1,665,000$ \\
\hline 1941 & - & $33,300,000$ & $33,300,000$ & $f$ & $1,248,750$ \\
\hline 1942 & - & $27,600,000$ & $27,600,000$ & $f$ & $1,035,000$ \\
\hline 1943 & - & $22,800,000$ & $22,800,000$ & $f$ & 855,000 \\
\hline 1944 & - & $31,800,000$ & $31,800,000$ & $f$ & $1,192,500$ \\
\hline 1945 & - & $29,100,000$ & $29,100,000$ & $f$ & $1,091,250$ \\
\hline \multicolumn{6}{|c|}{$\begin{array}{l}\text { a Stranges (1984) provides output figures for ICl's Billingham plant in tons of petrol-from-coal. We have converted tonst } t \\
\text { gallons by using the Institute of Fuel (1936) estimate of a conversion factor of } 300 \text { gallons to } 1 \text { ton of petrol from coal. } \\
\text { b Total direct subsidy is based on a preference of } 8 \mathrm{~d} \text { per gallon of fuel (1928- April 1938) and } 9 \mathrm{~d} \text { per gallon of fuel (April } \\
1938-1950) \text {, and } 240 \mathrm{~d} \text { to } f 1 \text {. }\end{array}$} \\
\hline
\end{tabular}

\subsection{State-industry relations}

$\mathrm{ICl}$ had a close relationship with the government. First, Brunner was a highly respected chemical firm that had worked closely with the government in research and manufacture contracts during WWI (Reader, 1975; Parke, 1957). Second, Alfred Mond who became Managing Director of Brunner and later Managing Director of ICl had been a senior politician between 1906 and 1923, holding a seat in cabinet from 1921 to 1922 (Bolitho, 1933). His political connections allowed him converse and lobby at high level. Third, ICI recruited a number of senior civil servants, who had the skills and experience to manage a large bureaucratic organisation (Grove, 1962). Their knowledge and experience within the British government would prove to be crucial for negotiations with the Board of Trade (Reader, 1975). Finally, Harry McGowan, Managing Director of ICl and later Chairman, had close ties with, Walter Runciman (Reader, 1977), who was President of the Board of Trade when ICI reached the later stages of negotiating with the Board. Both men had met through the Economic League, a pro-capitalist pressure group comprising of leading industrialists and the Anglo-German Fellowship, a group of industrialists focussed on building commercial links with Germany (Mclvor, 1988).

While these close connections provided ICl with preferential access to senior civil servants and politicians, as we have seen, $\mathrm{ICl}$ struggled to secure a subsidy for over five years. Initially, ICI had believed coal hydrogenation for petrol production would be economically attractive, and even if the cost was 'slightly' more than petroleum-based liquid fuels, energy security and coal industry employment concerns would mean that the government would likely subsidise the fuels. However, after oil scarcity fears were eradicated by new finds in the late 1920s, it became apparent that it was unlikely to ever be competitive with conventional motor spirits without government support. 


\subsection{The economic case for petrol-from-coal}

The British government was initially optimistic about coal hydrogenation's potential to reduce Britain's reliance on foreign oil (CID paper 598-B, 1925). By 1936, just one year after ICl opened Britain's first commercial scale plant, however, the limitations of Britain's coal hydrogenation efforts became clear. Falling oil prices and rapid growth in demand for motor spirits meant that many politicians and industrialists viewed the project as an expensive experiment with high opportunity cost (Institute of Fuel, 1936). By 1937 petrol-from-coal contributed just 2.5 per cent of total British light motor fuel consumption, whilst other alternatives including Benzol and alcohol fuels contributed just 8 per cent (Figure 1; Egloff, 1938).

Although ICl was secretive about profit margins, claiming commercial sensitivity, by 1937 it openly stated that costs had not fallen as expected and without subsidisation production would cease.

'For the general commercial reasons it is not the practice of the company to disclose the financial results of any particular activity. All that I can say, therefore, in regard to the hydrogenation plant is that up to date it has not shown results that would justify its description as a good commercial proposition, even with the advantages of the existing customs duty, and without that protection, of course, the enterprise would be uneconomic.' (Sir Harry McGowan, ICl Annual Meeting, April 29, 1937, cited in Egloff, 1938: 1093))

In a memorandum ICl provided to the Ministry of Power's investigation into coal derivatives in 1960, however, $\mathrm{ICl}$ acknowledged that while it had 'modest but real hopes of making a profit' from the venture, by 1938 it was 'barely paying its way and was contributing only a token amount to profits.' (Ministry of Power, 1959-60: 71).

This was supported by two economic appraisals (Rivett, 1937; Falmouth Committee, 1938) and remained the case during and after WWII (Payton-Smith, 1971). Both the Rivett Review and Falmouth Committee reports recommended no further support for coal hydrogenation, but suggested investigation into the competing Fischer-Tropsch process. Following the conclusions of the Falmouth Committee, APOC and Powell Duffryn Associated Collieries of South Wales, who had already been collaborating on tests of oil-coal mixtures as a furnace fuel in ships, considered a plan to erect a pilot Fischer-Tropsch plant (Payton-Smith, 1971). Both firms concluded, however, that there was no commercial case (Payton-Smith, 1971; Bamberg, 1994).

ICl's originally hoped that coal hydrogenation might be, with government support, a way forward for the stranded assets of the Billingham plant. In the event, however, the process was only cost-competitive with petroleum-derived fuels when oil prices were high and only commercially attractive with a stateguaranteed preference for home-produced hydrocarbon fuels.

Toward the end of 1938, and as Britain began to accelerate rearmament, the Air Ministry commissioned Fuel Research Board director, Sir Harold Hartley, to examine potential sources for high-octane aviation spirit. Hartley's commission recommended the building of three new hydrogenation plants to manufacture iso-octane that could be blended with Billingham's high-octane hydrogenated fuel. Plans were developed for ICl and Royal Dutch Shell and Trinidad Leaseholds to construct and run a further three plants in Heysham and Thornton (Lancashire) and in Trinidad. The Trinidad plans were quickly abandoned, while the Heysham plant was completed in 1941, the year in which the third plant at Thornton was abandoned. There was a brief period of renewed interest in coal hydrogenation after WWII, as fears rose that the US might restrict oil exports (Stranges, 1984), but new discoveries of oil in the Middle East and the US quickly removed those fears. Additionally, the price of coal, and therefore, creosote increased relative to oil, further reducing the competitiveness of the fuel. Guaranteed preference for coal hydrogenation and 
domestic production of light hydrocarbons continued until 1950 and by 1958, production ceased at Billingham (Kirk, 1998).

Petrol-from-coal hydrogenation continued to be developed by Spain, Japan and later South Africa for reasons associated with resource availability and various manifestations of energy security (San Román \& Sudriá, 2010; Stranges, 1993). Proposals for synthetic liquid fuels from coal continued to be explored in Britain throughout the $20^{\text {th }}$ century, particularly during the two oil crises in the late 1970 s and early 1980 s (Kimber, 1992) . None, however, came to fruition. The hydrogenation process, however, did contribute to significant developments in the crude oil refining sector, and the remaining plants in Britain and Germany were used for this purpose once the production of synthetic petrol ceased.

\section{Key features of the case studies and the analytical themes}

In order to clarify and compare the key features of the case-studies, a summary is provided in Table 2 . The discussion section is preceded by Table 3 which summarises the analytical themes. 


\begin{tabular}{|c|c|c|}
\hline Feature & DCL & $\mathbf{I C l}$ \\
\hline Fuel & $\begin{array}{l}\text { - } \quad \text { Alcohol produced by fermentation and blended with oil- and } \\
\text { coal-based fuels (e.g. petrol and benzole) } \\
\text { - } \quad \text { High octane, equivalent to No.1 grade petrol } \\
\text { - } \quad \text { Branded as Discol, later Cleveland-Discol }\end{array}$ & $\begin{array}{l}\text { - Identical to petroleum-derived petrol and easily blended with petrol } \\
\text { - } \quad \text { High octane, equivalent to No. } 1 \text { grade petrol } \\
\text { - } \quad \text { Unbranded, blended with petrol and marketed by BP Shell Mex Ltd }\end{array}$ \\
\hline $\begin{array}{l}\text { Raw materials and } \\
\text { feedstocks }\end{array}$ & - Imported molasses & - British coal (pulverised coal or coal derived creosote) \\
\hline Technology & - $\quad$ Produced using the Coffey still & $\begin{array}{l}\text { - Used high temperature and pressure engineering developed in parallel } \\
\text { to, and used similar engineering as, the Haber-Bosch process }\end{array}$ \\
\hline Nature of business & $\begin{array}{l}\text { - Market-led amalgamation } \\
\text { - } \quad \text { Business diversification led to power alcohol production } \\
\text { - } \quad \text { Influential industry voice exerted through market power }\end{array}$ & $\begin{array}{l}\text { - Government supported amalgamation driven by the need to support the } \\
\text { 'strategic' chemical industry, and international competitiveness, viz. } \\
\text { Germany and US large amalgamations IG Farben and Du Pont }\end{array}$ \\
\hline Drivers for new markets & $\begin{array}{l}\text { - Falling whisky sales and overproduction prompted search for } \\
\text { new products and markets, one of which was power alcohol } \\
\text { - Growing demand for petrol as vehicle fleet expanded }\end{array}$ & $\begin{array}{l}\text { Overcapacity in nitrogen fertiliser market a key driver for pursuit of new } \\
\text { markets and need to utilise capital intensive high pressure, large-scale } \\
\text { hydrogen production equipment at Billingham }\end{array}$ \\
\hline Nature of new markets & $\begin{array}{l}\text { - Alcohol for power alcohol produced by DCL (monopoly } \\
\text { production) } \\
\text { - Alcohol for power alcohol sold to Cleveland Petroleum for } \\
\text { sales and distribution } \\
\text { - Power alcohol subject to Government Excise production } \\
\text { restrictions }\end{array}$ & $\begin{array}{l}\text { - ICI held British Empire rights for hydrogenation patents (monopoly } \\
\text { production) } \\
\text { - Petrol sold to BP-Shell-Mex, and were monopsony buyers } \\
\text { - Empire rights granted through the IHP and IHEC limited technology } \\
\text { development in terms of imposed production quotas and unfavourable } \\
\text { RD\&D conditions }\end{array}$ \\
\hline Government support & $\begin{array}{l}\text { - Defence/military: DCL involved in acetone production during } \\
\text { both World Wars } \\
\text { - State support: } \\
\circ \text { Direct: Government subsidy received } \\
\circ \quad \text { Indirect: Government alcohol fuel R\&D and fuel } \\
\text { testing }\end{array}$ & $\begin{array}{l}\text { - Defence/ military: Strong links to defence concerns: navy, aviation and } \\
\text { land vehicles during wartime } \\
\text { - Industry--government relationships: Exercise of influence within } \\
\text { government to develop framework of cooperation for discussions on } \\
\text { subsidisation of process } \\
\text { - State support: } \\
\quad \text { Direct: Stimulate domestic production through markets, hence } \\
\quad \text { fuel had to be economically competitive } \\
\circ \quad \text { Indirect: Government led research early on, and fuel testing }\end{array}$ \\
\hline International context & $\begin{array}{l}\text { - Molasses used in power alcohol production imported from } \\
\text { Britain's colonies } \\
\text { - } \quad \text { Power alcohol could be produced more cheaply abroad } \\
\text { Other European countries mandated the use of alcohol in } \\
\text { motor spirit }\end{array}$ & $\begin{array}{l}\text { - } \quad \text { ICI part of the IHP } \\
\text { - Germany's earlier experience demonstrated that petrol-from-coal not } \\
\text { economically competitive with petroleum derived liquid fuels } \\
\text { Post WWII - Spain, South Africa and Japan developed large } \\
\text { programmes }\end{array}$ \\
\hline
\end{tabular}




\begin{tabular}{|c|c|}
\hline Analytical theme & Main aspects \\
\hline Energy security concerns & $\begin{array}{l}\text { Aspects of energy security driving support for domestic fuel production: } \\
\text { - Fuel scarcity } \\
\text { - } \quad \text { Dependence on non-domestic sources of fuel } \\
\text { - } \quad \text { Desire to maintain balance between overall imports and exports }\end{array}$ \\
\hline State support & $\begin{array}{l}\text { - Government unprepared for the manufacture of munitions in WWI } \\
\text { - Britain falling behind Germany in terms of the emerging chemical } \\
\text { industry }\end{array}$ \\
\hline Strategic industries and organised support & $\begin{array}{l}\text { - } \quad \text { Government increased engagement with scientific research and } \\
\text { strategic industries during WWI } \\
\text { - } \quad \text { Increased government intervention in strategic industries } \\
\text { - The Department for Scientific and Industrial Research (DSIR) } \\
\text { established in } 1916 \\
\text { - The government-run Fuel Research Station opened in } 1919\end{array}$ \\
\hline Government and industry relationships & $\begin{array}{l}\text { - Wartime supply contracts increased contact between government } \\
\text { and industry } \\
\text { - Government personnel were recruited into industrial organisations }\end{array}$ \\
\hline Fuel distribution & $\begin{array}{l}\text { - The fuel distribution monopoly was unregulated by government } \\
\text { - Fuel distribution ownership by the oil company 'Combine' made it } \\
\text { difficult for non-petroleum fuels to enter the market }\end{array}$ \\
\hline Patent pool agreements & - Patent pool agreements limited alternative fuel developments \\
\hline
\end{tabular}




\section{Discussion: Insights from ICl and DCL's common experiences}

This section reflects on how common experiences influenced the development of the two motor spirits providing detail on state support, government-industry relations, and the role of oil majors in fuel distribution. Each section provides a short overview of the background detail in each of these areas before discussing the impacts on DCL and ICl. Through these issues we illustrate how the broader economic and socio-technical contexts worked in favour of, or against, the development and use of power alcohol and petrol-from-coal. First, however, we describe the role of energy security, as this has emerged as a key underlying theme.

\subsection{Energy security}

The dynamics of energy security around fuel scarcity, dependence on foreign imports, and the trade balance prior to, and during the inter-war period, acted as a driving force for government to support domestic fuel production. For example, the impact of fears around an energy crisis during the 1920s provided the underlying rationale in government for extending the allowance on industrial alcohol to power alcohol (from 1921) to encourage its production in larger quantities (Yergin, 2009). Even when oil became more readily available, scarcity of supply concerns combined with the two 'oil price shocks' experienced in Britain eventually led to the passing of the British Hydrocarbon Oils Production Act in 1934. The Act was specifically developed to enable ICI to develop an experimental industrial-scale plant with coal hydrogenation, but also aimed to stimulate the production of other hydrocarbon liquid fuels.

Both case-studies provide evidence that notions of energy security played a significant role in the framing, shaping and timing of state support for domestic production of motor spirits. Throughout the inter-war period, energy security in relation to petroleum received considerable political, scientific, and societal attention. ICI and DCL both tailored their lobbying accordingly. As the case studies illustrate, three issues; fuel scarcity, dependence on non-domestic sources of fuel, and the desire to maintain a balance between overall imports and exports, were used to highlight the potential of alternative fuels to reduce Britain's dependence on imported liquid fuels. For example, ICl consistently highlighted the importance of coal for energy independence during peace and war time, and the impact it would have on Britain's balance of payments during its negotiations with the Board of Trade (Reader, 1977). Drawing issues of sovereignty together with raw materials, DCL emphasised that the raw materials for power alcohol were available not only at home but also within the Empire.

State interest in security of supply of liquid fuels prevailed throughout the inter-war period both in terms of its controlling interest in APOC but also through the Oil Fuel Board, a sub-committee of the Imperial Defence Committee. Within this forum, sovereignty over petroleum resources and scarcity of supply was a key driver for discussions about direct support for domestic motor spirit production.

\subsection{State support}

During WWI and the inter-war period, the government, as well as dealing with energy security concerns, were mindful of the need for defence materials more broadly. Before WWI, state-industry interactions had been limited in terms of sharing knowledge, resources and state intervention (Edgerton \& Horrocks, 1994). When hostilities broke out in summer 1914, however, the government found itself unprepared (Parke, 1957). Production of armaments could barely keep up with demand and quality was inconsistent. Rumours began to circulate that ammunition was being rationed, creating public outrage (Parke, 1957; Pattison, 1983). State engagement with, and support for, scientific research and strategic industries was now seen as necessary and urgent. 
Furthermore, received wisdom during this period was that Britain had begun to fall behind Germany and the US in the 'second industrial revolution', particularly in terms of the emerging heavy chemical industry (Haber, 1971; Reader, 1977; see Edgerton, 1996, for a discussion exploring Britain's 'industrial decline'). During WWI severe criticisms of Britain's flagging technological prowess were voiced by high profile political figures, including Lords Haldane and Balfour. Both looked to Germany's chemical industry as an exemplar due to its rapid transformation into a world leader (MacLeod \& Andrews, 1969; Marsch, 2000).

$\mathrm{ICl}$, with its capacity and experience for producing chemicals with a militaristic purpose and DCL, with its capacity for producing large quantities of alcohol which could be used in munitions, were both considered to be strategic industries. In addition, ethyl alcohol produced by DCL was an essential raw material for the chemical industry, the development of which was one of the reasons for ICl's creation. For these reasons, both $\mathrm{ICl}$ and $\mathrm{DCL}$ became a focus of government attention.

\subsubsection{Strategic industries and organised research}

During WWI, there was a shift from laissez-faire ideology to one of state intervention. From 1914/15 the state took a central role in planning, financing, and directing the activities of strategically important manufacturing firms (Hannah, 1983). This led, in 1915, to the formation of a Committee for Scientific and Industrial Research, charged with promoting research in industry and education. It became the Department for Scientific Industrial Research (DSIR) in 1916.

Despite the return to a more free-market ideology after the War, the government continued to recognise the importance of strategic industries and supported them. The DSIR played a key role in indirect state support for $\mathrm{ICl}$ and DCL's motor spirits in two ways. First, its preferred method was to support industrialists in highly specialised sectors including the chemical industry, to form research associations subsidised by government funds. For example, two DSIR grants to the British Colliery Owners' Research Association in the early 1920 s provided funds for academic research into coal hydrogenation at Birmingham University; the earliest evidence of state support for this emerging technology (Stranges, 1984).

Second, the DSIR itself also undertook research that was considered to be of national importance but was deemed unsuitable to be carried out by private enterprise (Sayer, 1950). DCL's power alcohol and ICl's petrol-from-coal were both considered strategically important and were therefore supported by government. DSIR supported power alcohol by arranging funding for, and initiating, the testing of power alcohol in a fleet of London's Omnibuses (The Times, 1920) (a task replicated by the government a century later in the testing of hydrogen fuel in buses (O'Garra et al., 2005)). DSIR also provided finance for the BBS to acquire patent licences for coal hydrogenation (Stranges, 1984). Furthermore, DSIR's commitment to research led to the formation of Departmental research stations, including the Fuel Research Station (FRS) established in 1919. This played a significant role in developing coal hydrogenation processes and fuel testing.

The establishment of the DSIR and FRS demonstrated governmental commitment to the exploration of alternative fuels, underpinned by the notion of their potential strategic importance. Both government organisations worked closely with $\mathrm{ICl}$ and $\mathrm{DCL}$, as we describe below.

\subsubsection{Government and industry relationships}

Both World Wars had significant influence on DCL's and ICl's government relationships. Due to the shortages of essential supplies during WWI, state-industry relationships grew closer, mainly through supply contracts. In order to address munitions concerns, different government departments interacted with industry. In 1917, for example, the Advisory Committee on Alcohol Supplies, in search of alcohol and acetone supplies for munitions, established a pattern of interaction between distillers and government 
over alcohol supplies that continued throughout the inter-war period and WWII (Weir, 1975). Similarly, the chemical firm Brunner, worked closely with the Ministry of Munitions in manufacture and research contracts during WWI (Reader, 1975). In addition, the military were also interested in alternative liquid fuels. Both the Admiralty and the Air Ministry played a considerable role in RD\&D of alternative fuels, working closely with the fuels produced by $\mathrm{ICI}, \mathrm{DCL}$, and other firms developing liquid fuels such as Low Temperature Carbonisation Ltd. (see for example, Oil Fuel Board, 1931).

Government and industry relationships and greater mutual understanding also benefitted from the sharing of personnel. The size and scope of ICl's and DCL's businesses, begun as a result of the second industrial revolution and intensified through the amalgamation movement, gave them the capability to communicate with, and influence both government and industry. The amalgamation movement more generally transformed industrial organisation and required experienced managers. They were often recruited into industry from senior positions in the civil service for their understanding of large bureaucratic institutions. For example, W.H. Coates and Josiah Stamp were both senior civil servants from the Inland Revenue recruited into senior $\mathrm{ICl}$ management positions early in its history. This, combined with interaction with various government departments contributed to the creation of a 'revolving door' giving $\mathrm{DCL}$ and $\mathrm{ICl}$ opportunities to influence government policy at the highest level and an appreciation of how to exert that influence (Weir, 1995; Reader, 1977).

For both $\mathrm{ICl}$ and $\mathrm{DCL}, \mathrm{WWI}$ supply contracts with government established close relationships with state actors and institutions. This, combined with the size and scope of both businesses, and a broader understanding of government organisation and process, privileged communication and influence.

\subsection{Oil major hegemony: fuel distribution and patent pool agreements}

DCL and ICI had similar experiences with the oil majors (viz. Standard Oil, Royal Dutch Shell and AngloPersian) and their cartels. Two types of cartel affected ICI and DCL; those controlling market arrangements and those governing patent pools.

In terms of market arrangements, a report investigating petrol prices (Report on Motor Fuel 1920) recommended that the newly established League of Nations act as vehicle for international regulation of the oil market. However, within this new institution there was no precedent for such a move and no action on regulation was taken. Similarly, the Board of Trade rejected recommendations to regulate the restrictive market structure created by the cartels at both international and domestic levels (Bridgeman, 1920). The view advocated by them, and repeated in the Balfour Committee report of 1927, was that while a monopoly represented market failure, the benefits outweighed the costs.

At the domestic level, the 1920 report advocated setting maximum and minimum retail prices under the Profiteering Act of 1919. The Board of Trade also rejected this proposal (Dixon, 1963). Whilst government documents published at the time do not make it clear why recommendations to regulate oil cartels were not approved, a case put forward in 1929 by the oil majors and their distribution subsidiaries offers some insight (Board of Trade, 1929; Economist, 1929). In this, the oil majors suggested to government that their products were the only ones to guarantee quality. They argued they were making substantial infrastructure and oil exploration investments, whereas firms such as DCL's distributor, Cleveland, were considered 'independents' and 'pirate' firms, who were unable to make such investment. This perspective was later confirmed in a 1965 report by the Monopolies Commission which implied that, during the inter-war period, the state was keen to attract private investment into the fuel distribution infrastructure. We suggest that this may have contributed to their reluctance to involve themselves with oil markets.

The second type of cartel involved oil majors in patent pool agreements. These were cartels that developed around specific technologies or processes, limiting their development. Patent pool agreements existed for 
both coal hydrogenation and power alcohol, in the form of the International Hydrogenation Patent (IHP) and the International Sugar and Alcohol Company (ISACo). The ISACo included German patent holders Prodor and Goldschmidt, Anglo-Persian, and the National Benzole Company as members, all of whom committed to sharing power alcohol patents. Little is known about the ISACo except that it wasn't long lived as oil companies removed their support early on, choosing instead to focus on alternative fuel enhancing processes (Bamberg, 1982). In contrast, the IHP, the result of several years of negotiation between BASF and later IG Farben and Standard Oil, placed strict restrictions on how the coal hydrogenation technology could be used, and stipulated that any technological discoveries or modifications to the process by licensees had to be shared with the IHP. Only IG Farben was permitted to use the technology for purposes other than petrol production. This reduced the economic attractiveness of large-scale production for ICI (Nowell, 1994). Furthermore, the extant market-sharing cartels meant that even if only one of the oil majors were involved in the patent pool agreements, all would be permitted to market the fuel in Britain (Nowell, 1994).

So while subsidies issued by the Board of Trade were provided to support DCL's and ICl's emerging fuels, the fuel distribution situation hindered the likelihood of their success. The Oil Fuel Board and other commentators such as the Economist recognised this inconsistency and the potential hostility of the oil majors to alternative fuels (Oil Fuel Board, 1930; Economist, 1927). For example, the Board reported in 1930 that, 'It is clear...that the production of oil from coal by hydrogenation might be meet [sic] with formidable opposition from the oil companies.' (Oil Fuel Board, 1930: 48). Non-interference was, however, implicitly endorsed by the government.

\subsection{Differences between ICl and DCL case-studies}

Whilst $\mathrm{ICl}$ and $\mathrm{DCL}$ shared experiences, as described above, differences did exist. Both $\mathrm{ICl}$ and $\mathrm{DCL}$ were 'combines' themselves, but $\mathrm{ICI}$, belonging to the category of 'strategic industry' received direct support from government on this basis. Until WWI, distilling had not been considered a strategic industry but the requirement for munitions alcohol brought government attention and association. Whereas subsidies were given to $\mathrm{ICl}$ to assist in the development of an experimental technology, $\mathrm{DCL}$ received support for an existing product which had come to assume great significance and had the potential to satisfy some key energy security concerns. However, as government became more confident about the uninterrupted availability of petrol supplies following WWII the need to support both fuels subsided.

A further difference was that the feedstock for ICl's fuel was non-renewable fossil fuel, whereas DCL's was renewable. At the time, whilst the 1919 Committee appointed to explore the potential of power alcohol recognised the advantages of a sustainable raw material, they were in the minority and any rhetoric in support of the development of power alcohol put little emphasis on this property. A final difference was that the petrol-from-coal developed by $\mathrm{ICl}$ did not receive any special marketing denoting the origin of the raw material. As petrol-from-coal it was simply blended with petrol derived from oil and sold as petrol. However, for DCL, power alcohol was branded 'Discol' (later 'Cleveland-Discol') and was promoted on the basis of it being an alcohol fuel made in Britain and with superior qualities over petrol. Nevertheless, as oil refining techniques advanced, and with increasing use of tetra-ethyl lead during the 1920 s as a cheap fuelenhancing petrol additive, power alcohol's advantages over petrol were gradually eroded. 


\section{Conclusions and policy implications}

In this study we adopted an historical approach to better understand the development of alternative fuels to petrol in the UK. We examined how both fuels were affected by political thinking around energy security and by oil major hegemony, and why and under what macro-economic conditions state support was provided. In this section we review how DCL's and ICl's experiences resonate with energy policy today.

We found that there was no one specific cause for either state support or the demise of these two fuels. Motivations for government support for alternative liquid fuels were dynamic and diverse. They included attempts to claw back British leadership in the synthetic chemical industry in the early 1920s, the need to find ways of modernising a crumbling domestic coal industry in the mid-1920s, and a means of rebalancing trade deficits to stabilise public debt. Added to this was the prevailing recession in the early-1930s and the need for rearmament. All of these factors contributed to building a case for supporting the production of domestic fuels.

From an industry perspective, both $\mathrm{DCL}$ and $\mathrm{ICl}$ experienced downturns as a result of changing market requirements for their products and, as a result, sought to diversify and find new markets. The swing towards resource nationalism during the 1930s meant that both companies were able to capitalise on government support for domestic industries. Exponential growth in the motor car industry and increasing social acceptance of liquid fuels provided potential markets in which to expand with new, home-produced, motor fuels. However, the oil companies were taking advantage of the same socio-economic-political situation. The case-studies illustrated that the new markets identified by $\mathrm{ICl}$ and $\mathrm{DCL}$ were intimately tied to, and dependent on, the fuel distribution infrastructure which was owned by oil companies. Expectations within government that the oil industry would provide the necessary infrastructure and continue with oil exploration addressed fuel security concerns and perpetuated close relations.

Government adopted a dual approach to fuel security; maintaining a controlling interest in APOC and providing subsidies for alternative fuels to petrol. The inter-war period was arguably the first time that Britain faced the implications of growing dependence on imported energy resources - implications which have affected UK energy policy ever since. We saw that energy security, as it related to defence, resulted in the privileging of fuel as a 'special article of warlike material'. Under this classification, state intervention was deemed necessary and the government closely worked with oil companies to achieve a secure fuel supply. This placed $\mathrm{DCL}$ and $\mathrm{ICl}$ in the middle of a policy environment where state subsidisation of liquid fuels conflicted with the broader view on cartelisation, contributing to the poor economic feasibility of both fuels. Whilst the overarching view in government may have been to secure fuel supplies, multiple options for satisfying these concerns were available. From the case-studies it is evident how various options were represented by different interests, including defence, manufacturing, and the coal industry, and how these interests shaped the policy environment. Through its approaches government succeeded in securing fuel (petroleum) supplies and encouraging the production of small amounts of alternative fuels. But in doing so it also increased Britain's dependence on imported fuels.

Energy security problematised issues which varied along sliding scales of cost and availability. Variations in the perceived availability and actual cost of oil for petrol and the raw materials used for producing alternative fuels e.g. molasses, oil, and coal, contributed to how solutions to energy security were framed and prioritised. ICl and DCL used cost and availability arguments to their advantage to obtain government support, adding matters such as defence requirements and national identity to further their cases at different times. The changing shape of energy security therefore meant that government's ways of securing fuel supplies were not necessarily the cheapest option. By the time energy security concerns faded, reviews of the financial supports provided to $I C I$ and $D C L$ considered them too expensive and they 
were subsequently removed. Here we can recall Grimston (2010) and Helm (2005), who both make the case that fuels, and energy, are, at times of insecurity treated as 'special cases'. Both case-studies illustrated this point as, at times of insecurity, the priority of the state to secure fuel supplies justified expensive state intervention. Cost and availability considerations therefore meant that greater costs were permitted under conditions of actual, or anticipated, supply shortage.

From WWI onwards, fuel oil was considered a 'special article' for war, rather than a general commodity. It was, therefore, not subject to 'ordinary' market conditions, reflecting a shift towards a more state-led governance logic. During the inter-war period, however, as government relied more on the market for the production and delivery of fuel whilst providing implicit support through non-regulation of the fuel distribution market, the balance changed more towards a market-led logic. This illustrates the dynamic nature of governance logics, which shift along a spectrum rather than existing as absolutes (see Figure 2). The inter-war period therefore represented a combination, or hybrid, of market- and state-led logics. Within this mode of governance different representations of the 'best' solution existed simultaneously, which led to conflicting policy measures. However, the case-studies illustrate that the hybrid governance situation itself contributed to obscuring the longer-term implications of the decisions that were taken. As oil supplies became more certain, from around 1926, the government's commitment to securing energy supplies favoured oil company developments over alternative domestic fuel sources. However, as energy insecurity intensified in the years preceding WWII, there was a return to a more state-led mode of governance. The case-studies demonstrate that the tension between the market and state logics meant that the government simultaneously and knowingly supported an unregulated fuel distribution market whilst providing subsidies for alternative fuels.

Whilst the UK government's decision to support both petrol and alternative fuels appeared sensible in terms of securing the physical supply of fuel, its lack of oil industry regulation made it difficult for new entrants like $D C L$ and $I C I$ to gain a market share. There was an unwillingness within government to regulate the fuel distribution system and to make it open to third parties specifically. The government's failure to address regulation in this way meant that their security aims could not be obtained through market mechanisms alone. Today's regulatory structures can impose obligations on industry, for example, the Renewable Transport Fuels Obligation Order (2007), which requires $4.75 \%$ of total road transport fuel to be biofuel (April 2013). Obligations such as this provide policy tools for ensuring that market incumbents accommodate new entrants. However, there were no purchase or blending obligations in the 1930s, which might have been used to support alternative fuels. Both case-studies illustrated that this was a contributing factor in their demise.

Although it has been argued that regulation can be seen as a way of depoliticising energy and fuel supplies (Abbasov, 2014), as we have seen, balancing the 'special commodity' status of energy, in which the market is not solely responsible for delivery, with government intervention and regulation is often problematic. One means of addressing this problem of energy governance is the creation of integrated industrygovernment groups. Whilst government and industry integration was initially experienced through defence contracts during both Wars, new institutions, e.g. the Economic Advisory Board (EAB), were not formalised until the 1930s when they were able to promote support for domestic industries. Similar groups today which combine industry and government representatives, e.g. the Scottish Energy Advisory Board, offer one way of contributing to the production of mutually beneficial agreements, and working around potential difficulties and dependencies created by policy inconsistency.

We suggest that our historical analysis of alternative fuels in the inter-war period is useful for understanding the contemporary dynamics of energy policy. The case-studies presented here provide an historical example of current arguments, which emphasise the combined role of state and market in energy governance. Historical analysis also enables us to observe, with hindsight, the effects of these dynamics in government, industry and society. Challenges for energy policy today interweave climate change, energy 
security, and affordability (the energy trilemma), which combine with geopolitical energy security concerns such as resource sovereignty and supply. With the acknowledgement that the state plays a crucial role in the functioning of energy markets and institutions (e.g. de Graaff, 2013), state responsibilities for setting energy policies therefore need to be mindful of previous experience, where short-term decisions were taken without also taking a longer-term perspective.

An historical approach also enabled us to observe the effect of shifting modes of governance and illustrated how hybrid governance affected energy decision-making. We saw how energy security was framed and reframed over time, and contributed to a changing policy environment with consequent effects for power alcohol and petrol-from-coal. The flatter, less hierarchical, relational approach (Chilvers and Longhurst, 2013) we adopted enabled us to capture the diverse characteristics of the 'non-transition' or 'failed transition' of our alternative fuels. This revealed multiple, overlapping, and interacting transitions in combination with the roles played by politics and hybrid governance. 


\section{References}

1905 Committee (1905) Industrial Alcohol Committee. Report of the Departmental Committee on Industrial Alcohol. HMSO: London. (Cd. 2472). The National Archives, Kew, London.

1919 Committee (1919) H.M. Petroleum Executive. Report of the Inter-Departmental Committee on various matters concerning the production and utilization of alcohol for power and traction purposes. Cmd. 218. The National Archives, Kew, London.

Abbasov, F.G. (2014) EU's External Energy Governance: A multidimensional analysis of the southern gas corridor. Energy Policy. 65(0): 27-36.

Arapostathis, S., Carlsson-Hyslop, A., Pearson, P.J.G., Thornton, J., Gradillas, M., Laczay, S. and Wallis, S. (2013) Governing Transitions: Cases and insights from two periods in the history of the UK gas industry. Energy Policy, 52: 25-44.

Bamberg, J.H. (1994) The History of the British Petroleum Company: Volume 2, The Anglo-Iranian Years, 1928-1954. Cambridge University Press, Cambridge.

Bennett, S.J. (2009) The Socio-technical Dynamics of Chemical Feedstock Transitions: The case of renewable raw materials in the UK. PhD thesis, Imperial College London.

Bennett, S.J. and Pearson, P.J.G. (2009) From Petrochemical Complexes to Biorefineries? The past and prospective co-evolution of liquid fuels and chemicals production in the UK. Chemical Engineering Research \& Design, 87(9A), 1120-1139.

Bernton, H., Kovarik, W. and Sklar, S. (1982/2010) The Forbidden Fuel. Power Alcohol in the Twentieth Century. Boyd Griffin, New York.

Board of Trade (1929) Prices of petroleum products: Statements by the oil companies concerned. Cmd. 3296. Command Papers; Accounts and Papers. Volume XVI.685. The National Archives, Kew, London.

Bolitho, H. (1933) Alfred Mond: First Lord Melchett. Secker, London.

Bolton, R. and Foxon, T. (2013) Negotiating the Energy Policy 'trilemma' - An analysis of UK energy governance from a socio-technical systems perspective. In Theorising Governance Change for a Sustainable Economy. IGov Workshop, British Library, London 30 ${ }^{\text {th }}$ April, 2013.

Bowden, S. and Turner, P. (1993) Some Cross-Section Evidence on the Determinants of the Diffusion of Car Ownership in the Inter-War UK Economy. Business History. 34: 55-69.

Bridgeman, W. (1920) Written answers (Commons) of $22^{\text {nd }}$ March, 1920. House of Commons Hansard, Volume 127, Columns $64-65$.

Broadberry, S. (1986) The British Economy Between the Wars: A macroeconomic survey. Basil Blackwell Ltd, Oxford.

Brownlie, D. (1926) The Coal Question: Great Britain at the Crossroads. Fortnightly Review. March 1926; 119 (711), 376-387. 
Brunner, C. (1930) The Problem of Oil. Ernest Benn Limited, London.

Cadman, J. (1931) British Fuel Problem: Oil. Chemistry and Industry, $6^{\text {th }}$ November, 908-912.

Carlsson-Hyslop, A. and Pearson, P.J.G. (2013) How did the Electrical Development Association Attempt to Mould Electricity Demand in Britain, 1945-1964. Realising Transition Pathways Working paper 2013/01. March 2013.

Chilvers, J. and Longhurst, N. (2013) Participation in Transition(s): Emergent engagement, politics and actor dynamics in low carbon energy transitions. Science, Society and Sustainability Research Group Working Paper, University of East Anglia, Norwich.

Commercial Motor Archive (1923) Alcohol as a Practical Fuel. 24 ${ }^{\text {th }}$ April 1923. (accessed 13/02/14) http://archive.commercialmotor.com/article/24th-april-1923/12/alcohol-as-a-practical-fuel

Department of Energy and Climate Change (DECC) (2013) Crude Oil and Petroleum: Production, imports and exports 1890 to 2012.

https://www.gov.uk/government/uploads/system/uploads/attachment data/file/224640/oil sinc e 1890 historical data.xls

de Graaff, N.A. (2013) Towards a Hybrid Global Energy Order: State-owned oil companies, corporate elite networks and governance. Doctoral Thesis, Vrije Universiteit, Amsterdam.

Department of Scientific and Industrial Research (DSIR) (1929) The Production of Oil from Coal: Memorandum submitted to the Oil Fuel Board. CAB 50/3 294-7. The National Archives, Kew, London.

Dintenfass, M. (1999) Converging Accounts, Misleading Metaphors and Persistent Doubts: Reflections on the historiography of Britain's 'decline'. In Dormois, J-P. and Dintenfass, M. (eds) The British Industrial Decline. Routledge, London.

Dixon, D. (1963) Petrol distribution in the United Kingdom, 1900-1950. Business History. 6: 1-19.

Dixon, D. (1997) Inter-war Changes in Gasoline Distribution: A US-UK comparison. Business and Economic History 26: 632-648.

Economist (1927) Petrol from Coal. $8^{\text {th }}$ January, p. 16.

Economist (1929) The Petrol Case. $23^{\text {rd }}$ March, p. 621.

Edgerton, D. (1996) Science, Technology and the British Industrial 'Decline', 1870-1970. Cambridge University Press, Cambridge.

Edgerton, D. and Horrocks, S. (1994) British Industrial Research and Development before 1945. The Economic History Review. 47: 213-238.

Egloff, G. (1938) Motor Fuel Economy of Europe. Volume II of Committee on Motor Fuels. Motor Fuel Facts Series, American Petroleum Institute.

Falmouth Committee (1938) Committee of Imperial Defence: Sub-committee on oil from coal: Report. London: HMSO (Cmd. 5665). 
Federal Oil Conservation Board (1926) Report of the Federal Oil Conservation Board to the President of the United States: Government Printing Office, Washington D.C.

Fitzgerald, P. (1927) Industrial Combination in England (European Business). Sir Isaac Pitman and Sons, London.

Flink, J. (1988) The Automobile Age. Massachusetts Institute of Technology, Massachusetts.

Foxon, T.J. (2013) Transition Pathways for a UK Low Carbon Electricity Future. Energy Policy, 52: 10-24.

Fudge, S., Peters, M., Mulugetta, Y. and Jackson, T. (2011) Paradigms, Policy and Governance: The politics of energy regulation in the UK post-2000. Environmental Policy and Governance, 21(4): 291-302.

Gardiner, J. (2010) The Thirties: An intimate history. Harper Press, London.

Geels, F.W. (2002) Technological Transitions as Evolutionary Reconfiguration Processes: A multi-level perspective and a case-study. Research Policy, 31(8-9): 1257-1274.

Greaves, J. (2005) Industrial Reorganization and Government Policy in Interwar Britain. Ashgate Publishing Ltd, Aldershot.

Grimston, M. (2010) Electricity - Social Service or Market Commodity? The Importance of Clarity for Decision-making on Nuclear Build. Chatham House, London.

Goldthau, A. (2012) From the State to the Market and Back: Policy implications of changing energy paradigms. Global Policy. 3: 198-210.

Grove, J. (1962) Government and Industry in Britain. Longmans Green and Co. Ltd, London.

Haber, L.F. (1971) The Chemical Industry 1900-1930: International growth and technological change. Oxford University Press, London.

Haber, F. (1986) The Poisonous Cloud: Chemical warfare in the First World War. Clarendon Press, Oxford.

Hannah, L. (1983) The Rise of the Corporate Economy. Methuen \& Co. Ltd, London.

Helm, D. (2005) The Assessment: The new energy paradigm. Oxford Review of Economic Policy. 21: 1-18.

Hughes, T.P. (1969) Technological Momentum in History: Hydrogenation in Germany 1898-1933. Past and Present. 44: 106-132.

Hughes, N. and Strachan, N. (2010) Methodological Review of UK and International Low Carbon Scenarios. Energy Policy 38: 6056-6065.

Jones, G. (1981) The State and the Emergence of the British Oil Industry. Macmillan Press, London.

Kakhki, M.M.H. (2008) A Critical Analysis of Iranian Buy-back Transactions in the Context of International Petroleum Contractual Systems. Durham theses, Durham University. Available at Durham E-Theses Online: http://etheses.dur.ac.uk/2931/ 
Kimber, G. (1996) A History of UK Coal Liquefaction, 1967 - 1992. COAL R078. Energy Technology Support Unit (ETSU), Harwell.

Kirk, F. (1998) Twentieth Century Industry: Obsolescence and change. A case study: The ICI coal to oil plant and its varied uses. Industrial Archaeology Review. 20: 83-90.

Labour Party (1938) Labour's Plan for Oil from Coal. The Labour Party Publications Department, London.

Lamer, M. (1957) The World Fertilizer Economy. Food Research Institute of Stanford University, Stanford, California.

Lawton, L. (1925) Coal and the Future. Fortnightly Review, August 1925. 118(704), 249.

Liberal Party (1928) Britain's Industrial Future: Report of the Liberal industries inquiry, 1928. Ernest Benn Ltd, London.

Linehan, D. (2003) Regional Survey and the Economic Geographies of Britain 1930-1939. Transactions of the Institute of British Geographers. 28: 96-122.

Macbeth, B.S. (1985) British Oil Policy 1919-1939. Frank Cass Ltd, London.

Macleod, R. and Andrews, E. (1969) The Committee of Civil Research: Scientific advice for economic development, 1925-30. Minerva, 7: 680-705.

Maddison, A. (2003) Historical Dataset of World GDP/ OECD. The World Economy: Historical statistics. OECD Development Centre, Paris.

Marsch, U. (2000) Transferring Strategy and Structure: The German chemical industry as an exemplar for Great Britain. In Lesch, J. (Ed.) The German Chemical Industry in the Twentieth Century. Kluwer Academic Publishers, Dordrecht.

Marsden, C.A. (1943) Verbatim oral evidence from Mr. C.A. Marsden given at a meeting of the Industrial Alcohol Committee on $21^{\text {st }}$ September 1943. T161/1407. The National Archives, Kew, London.

Marwick, A. (1964) Middle Opinion in the Thirties: Planning, process and political agreement. The English Historical Review. 79 (311): 285-298.

May Committee (1944/45) Industrial Alcohol Committee. Removal of Certain Excise Restrictions on Distillation and of Allowances on Industrial Alcohol and Exported Spirits. Cmd. 6622. The National Archives, Kew, London.

Mclvor, A. (1988) A Crusade for Capitalism: The Economic League, 1919-1939. Journal of Contemporary History. 23: 631-655.

Ministry of Power (1959-60) Report of the Committee on Coal Derivatives. Cmnd. 1120. The National Archives, Kew.

Mokyr, J. (1998) The Second Industrial Revolution, 1870 -1914. In Castronovo, V. (Ed.) Storia dell'economia Mondiale. Laterza Publishing, Rome. 
National Academy of Sciences (1977) Committee on Processing and Utilisation of Fossil Fuels, Commission on Sociotechnical Systems. Assessment of Technology for the Liquefaction of Coal: Ad Hoc Panel on Liquefaction of Coal. National Academy of Sciences, Washington D.C.

Nicholson, M. (1931) A National Plan for Great Britain. Week-End Review, February 14.

Nowell, G.P. (1994) Mercantile State and the World Oil Cartel 1900-1939. Cornell University Press, Ithaca.

O'Garra, T., Mourato, S. and Pearson, P. (2005) Analysing Awareness and Acceptability of Hydrogen Vehicles: A London case study. International Journal of Hydrogen Energy. 30(6): 649-659.

Oil Fuel Board (1925-39) Committee of Imperial Defence. Minutes and Memoranda. CAB 50. The National Archives, Kew, London.

Oil Fuel Board (1928) Committee of Imperial Defence. Memorandum by Secretary of the Oil Board. CAB 50/4. Paper No. 878B. The National Archives, Kew, London.

Oil Fuel Board (1929) The Production of Liquid Fuels from Coals. Memorandum by the Secretary of the Oil Board. CAB 50 3. The National Archives, Kew, London.

Oil Fuel Board (1930) Extraction of Oil from Coal. CAB 50/30, 351-363. The National Archives, Kew, London.

Oil Fuel Board (1931) Trials of Petrol Produced by Hydrogenation of Coal. CAB 50/4 O.B. 64. British Library, London.

Oil Fuel Board (1932) Committee of Imperial Defence. Meeting memoranda. CAB 50/4. The National Archives, Kew, London.

Oil Fuel Board (1933) Committee of Imperial Defence. Meeting memoranda. CAB 50/5. The National Archives, Kew, London.

Pattison, M. (1983) Scientists, Investors and the Military in Britain, 1915-19: The munitions inventions department. Social Studies of Science. 13: 521-568.

Parke, V.E. (1957) Billingham - The first ten years. ICI Ltd, Billingham.

Payton-Smith, D.J. (1971) Oil: A study of war-time policy and administration. London: HMSO.

Pearcy, J. (2002) Recording an Empire: An accounting history of Imperial Chemical industries Ltd. 19261976. The Institute of Chartered Accountants of Scotland, Edinburgh.

Pearson, P.J.G. and Foxon, T.J. (2012) A Low Carbon Industrial Revolution? Insights and challenges from past technological and economic transformations. Energy Policy, 50(0): 117-127.

Pettigrew, A. (1985) The Awakening Giant: Continuity and change in ICl. Basil Blackwell Ltd, Oxford.

Podobnik, B. (2006) Global Energy Shifts: Fostering sustainability in a turbulent age. Temple University Press, Philadelphia.

Pugh, M. (2008) We Danced all Night: A social history of Britain between the wars. Vintage Books, London. 
Reader, W.J. (1975) Imperial Chemical Industries. A History. Volume II. The First Quarter-Century 19261952. Oxford University Press, London.

Reader, W.J. (1977) Imperial Chemical Industries and the State, 1926-1945. In Supple, B. (ed). Essays in British Business History. Oxford University Press, Oxford.

Report on Motor Fuel (1920) Profiteering Act, 1919. Report on Motor Fuel Prepared by a Sub-Committee Appointed by the Standing Committee on the Investigation of Prices. Cmd. 597. The National Archives, Kew, London.

Richardson, H.W. (1961) The New Industries between the Wars. Oxford Economic Papers. 13(3), 360-384.

Rivett, D. (1937) Parliament of the Commonwealth of Australia. Oil Production from Coal Viewed from an Australian Standpoint. Session number 71, Volume V: 2435-2462.

Royal Commission on Fuels and Engines (1913) Royal Commission on Fuels and Engines: Volume 1. ADM 265/32. The National Archives, Kew, London.

Rydin, Y., Turcu, C., Guy, S. and Austin, P. (2013) Mapping the Coevolution of Urban Energy Systems: Pathways of change. Environment and Planning A. 45(3): 634-649.

San Román, E. and Sudriá, C. (2003) Synthetic Fuels in Spain, 1942-66: The failure of Franco's autarkic dream. Business History, 45: 73-88.

Sayer, R. (1950) The Springs of Technical Progress in Britain, 1919-1939. The Economic Journal. 60: 275-291.

Scott, P. (2002) British Railways and the Challenge from Road Haulage: 1919-39. Twentieth Century British History. 13: 101-120.

Second Report on Motor Fuel (1921) Prepared by a sub-committee appointed by the Standing Committee on the Investigation of Prices. Profiteering Acts, 1919 and 1920. Second Report on Motor Fuel. Command papers; Reports of Commissioners. Cmd. 1119. The National Archives, Kew, London.

Smil, V. (2004) Enriching the Earth: Fritz Haber, Carl Bosch, and the transformation of world food production. MIT Press, Cambridge, Massachusetts.

Smith, A., Stirling, A. and Berkhout, F. (2005) The Governance of Sustainable Socio-technical Transitions. Research Policy, 34(10): 1491-1510.

Stranges, A. (1984) Fredrich Bergius and the Rise of the German Synthetic Fuel Industry. Isis. 75: 642-667.

Stranges, A. (1985) From Birmingham to Billingham: High-pressure coal hydrogenation in Great Britain. Technology and Culture. 26: 726-727.

Stranges, A. (2000) Germany's Synthetic Fuel Industry, 1930-1945. In: Lesch, J.E. (Ed.) The German Chemical Industry in the Twentieth Century. Kluwer Academic Publishers, Dordrecht, pp.147-216.

The Institute of Fuel (1936) Informal Meeting: Economic and national aspects of the production of oil from coal. The Institute of Fuel 9: 277-82. 
Times (1913) The Price of Petrol. Producer and Consumer. The Times. Thursday, $2^{\text {nd }}$ January 2013, Issue 40098, p.8.

The Times (1920) Petrol Substitutes. Alcohol Tests to be Encouraged. Release of Weekly Supplies. The Times, Tuesday, $8^{\text {th }}$ June 1920, p.14.

Turnbull, M. (1973) Attitude of Government and Administration towards the 'Hunger Marches' of the 1920s and 1930. Journal of Social Policy, 2: 131-142.

United States Tariff Commission (1931) Report to the Congress on the Cost of Crude Petroleum. Government Printing Office, Washington D.C.

United States Tariff Commission (1937) Chemical Nitrogen: A survey of processes, organisation, and international trade, stressing factors essential to tariff consideration. Government Printing Office, Washington D.C. http://babel.hathitrust.org/cgi/pt?id=mdp.39015068215998;view=1up;seq=5

Weir, R. (1995) The History of the Distillers Company, 1877 - 1939: Diversification and growth in whisky and chemicals. Oxford University Press, Oxford.

Williamson, H. Andreano, R., Daum, A. and Klose, G. (1963) The American Petroleum Industry, Volume 2: 1899-1959. The Age of Energy. Northwest University Press, Evanston, Illinois.

Wood, J. (1996) The Motor Industry of Britain Centenary Book 1896-1990. Eclat Initiatives Ltd, Wickford.

Yergin, D. (2009) The Prize: The epic quest for oil, money and power. Free Press, New York. 